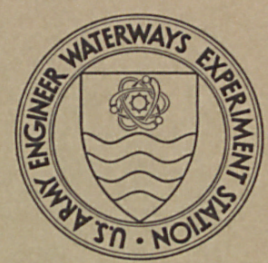

\title{
IN SITU SEISMIC INVESTIGATION ISABELLA PROJECT, CALIFORNIA
}

by

Glenn B. Landers and Joseph R. Curro, Jr.

Geotechnical Laboratory

U. S. Army Engineer Waterways Experiment Station

P. O. Box 631, Vicksburg, Miss. 39180

November 1978

Final Report

Approved For Public Release; Distribution Unlimited

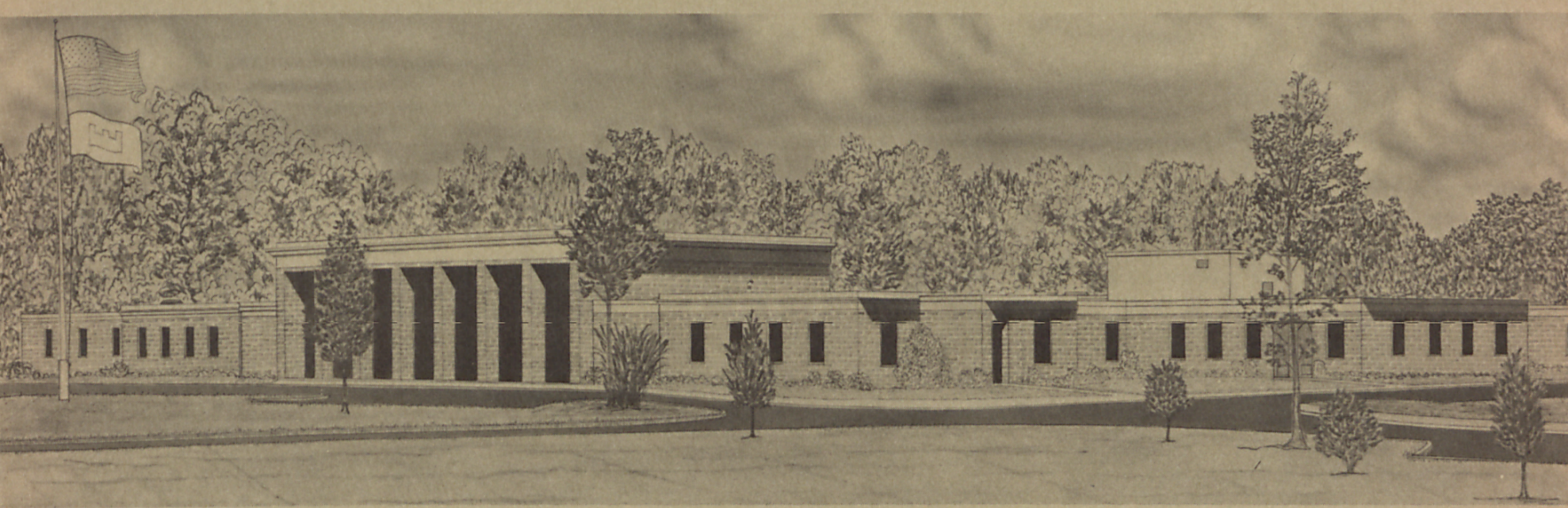

Prepared for U. S. Army Engineer District, Sacramento Sacramento, California 95814 


\section{DEPARTMENT OF THE ARMY \\ WATERWAYS EXPERIMENT STATION. CORPS OF ENGINEERS \\ P. O. BOX 631 \\ VICKSBURG. MISSISSIPPI 39180 \\ Errata Sheet \\ No. 1}

IN SITU SEISMIC INVESTIGATIONS,

ISABELLA PROJECT, CALIFORNIA

Miscellaneous Paper S-78-16

December 1978

Substitute Plate 3 attached hereto for Plate 3 bound in report. 


$$
2+5-8 \text { \& } 001
$$

\begin{tabular}{|c|c|}
\hline REPORT DOCUMENTATION PAGE & $\begin{array}{l}\text { READ INSTRUCTIONS } \\
\text { BEFORE COMPLETING FORM }\end{array}$ \\
\hline \begin{tabular}{l|l|} 
1. REPORT NUMBER & 2. GOVT ACCESSION NO. \\
Miscellaneous Paper S-78-16 &
\end{tabular} & 3. RECIPIENT'S CATALOG NUMBER \\
\hline \multirow{2}{*}{$\begin{array}{l}\text { 4. TITLE (and Subtit10) } \\
\text { IN SITU SEISMIC INVESTIGATION, ISABELLA PROJECT, } \\
\text { CALIFORNIA }\end{array}$} & $\begin{array}{l}\text { 5. TYPE OF REPORT \& PERIOD COVERED } \\
\text { Final report }\end{array}$ \\
\hline & 6. PERFORMING ORG. REPORT NUMBER \\
\hline $\begin{array}{l}\text { 7. AUTHOR(a) } \\
\text { Glenn B. Landers } \\
\text { Joseph R. Curro, Jr. }\end{array}$ & 8. CONTRACT OR GRANT NUMBER(0) \\
\hline $\begin{array}{l}\text { 9. PERFORMING ORGANIZATION NAME AND ADDRESS } \\
\text { U. S. Army Engineer Waterways Experiment Station } \\
\text { Geotechnical Laboratory } \\
\text { P. O. Box 631, Vicksburg, Miss. } 39180\end{array}$ & $\begin{array}{l}\text { 10. PROGRAM ELEMENT. PROSECT, TASK } \\
\text { AREA Q WORK UNIT' NUMBERS }\end{array}$ \\
\hline \multirow{2}{*}{$\begin{array}{l}\text { 11. CONTROLLING OFFICE NAME AND ADDRESS } \\
\text { U. S. Army Engineer District, Sacramento } \\
\text { 650. Capitol Mall } \\
\text { Sacramento, Calif. } 95814\end{array}$} & $\begin{array}{l}\text { 12. REPORT DATE } \\
\text { NOVember } 1978\end{array}$ \\
\hline & $\begin{array}{l}\text { 13. NUMBER OF PAGES } \\
45\end{array}$ \\
\hline \multirow[t]{2}{*}{ 14. MONITORING AGENCY NAME \& ADDRESS(It dilforent frod Controlline Offlco) } & $\begin{array}{l}\text { 15. SECURITY CLASS. (of thle report) } \\
\text { Unclassified }\end{array}$ \\
\hline & $\begin{array}{l}\text { 15.. DECLASSIFICATION/DOWNGRADING } \\
\text { SCHEDULE }\end{array}$ \\
\hline
\end{tabular}

SECURITY CLASSIFICATION OF THIS PAGE (When Dato Entorod)

16. DISTRIBUTION STATEMENT (Ol chlo Roport)

Approved for public release; distribution unlimited.

17. DISTRIBUTION STATEMENT (of the ebotract entored in Block 20, 1 difforent trom Roport)

18. SUPPLEMENTARY NOTES

19. KEY WORDS (Continue on reverce alde II noceecery. and Idontlfy. by. block. number).

Compression waves

Crosshole test

Geophysical investigation
Isabella Project

Seismic refraction

Shear waves

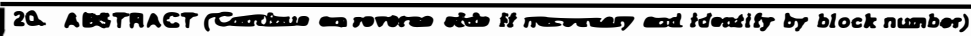

An in situ seismic investigation consisting of surface refraction seismic, dowahole, and crosshole tests was conducted at Lake Isabella, near Bakersfield, California. Compression and shear wave ( $P-$ and $S$-wave) velocities as a function of depth were determined for the main and auxiliary dams and underlying foundation materials.

Results at the main dam indicated four P-wave velocity zones from a

(Continued) 
Unclassified

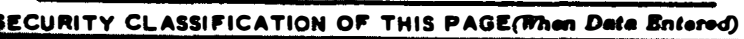

20. ABSTRACT (Continued).

surface refraction seismic line located along the crest of the dam. These zones had velocities of (a) 1,750 , (b) 2,550 , (c) 8,050 , and (d) 18,450 fps, which corresponded to (a) random fill material, (b) the central impervious core, (c) weathered granite, and (d) fresh granite.

Velocity data from crosshole and downhole tests conducted on the downstream face of the main dam indicated three $P$ - and S-wave velocity zones. The respective $P$ - and $S$-wave velocities were (a) 2,000 and $950 \mathrm{fps}$, (b) 3,750 and $1,300 \mathrm{fps}$, and (c) 16,700 and 4,700 fps, which corresponded to (a) and (b) random fill material, and (c) granite. The $P$ - and S-wave velocities of 3,750 and 1,300 fps, respectively, were established for the alluvium and horizontal drainage layer.

Data at the auxiliary dam were given two separate interpretations. The primary interpretation established three basic $\mathrm{P}$ - and S-wave velocity zones with respective velocities of (a) 2,850 and 1,150 fps for the embankment, (b) 6,600 and 1,600 fps for the foundation to bedrock, and (c) 12,100 and 3,300 fps for granite bedrock. The alternate interpretation provided a more detailed profile. Nine $\mathrm{P}$-wave and eight $\mathrm{S}$-wave velocity zones were established ranging from a low of 2,450 and 1,000 fps ( $P$ - and S-wave, respectively) to a high of $13,400 \mathrm{fps}$ ( $\mathrm{P}$-wave) and 3,750 fps (S-wave) for fractured granite.

Unclassified

SECURITY CLASSIFICATION OF THIS PAGE(Whon Date Entered) 


\section{PREFACE}

The in situ seismic investigation at the Isabella Project was authorized by the U. S. Army Engineer District, Sacramento, California, in IOA No. SPKED-F-77-26, Appropriation No. 96x4902.

The field investigation was conducted during the period 6-17 August 1977 by Messrs. J. R. Curro, Jr., G. B. Landers, D. H. Douglas, and E. S. Stewart, Jr., all of the Geodynamics Branch (GDB), Earthquake Engineering and Vibrations Division (EE\&VD), Soils and Pavements Laboratory (S\&PL), U. S. Army Engineer Waterways Experiment Station (WES). The analysis phase of this study was performed by Messrs. G. B. Landers and J. R. Curro, Jr., under the general supervision of Mr. R. F. Ballard, Jr., Chief, GDB; Dr. P. F. Hadala, Acting Chief, EE\&VD; and Mr. J. P. Sale, Chief, S\&PL. This report was written by Messrs. Landers and Curro.

The organization of laboratories at WES has undergone a structural change during the time interval since this study was conducted. The organizations and individuals listed above as incremental to S\&PL are now engaged under the Geotechnical Laboratory, Mr. James P. Sale, Chief.

COL J. L. Cannon, CE, was Director of WES during the performance of this investigation and the preparation of this report. Mr. F. R. Brown was Technical Director. 


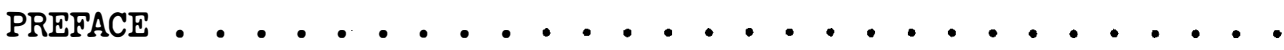

CONVERSION FACTORS, U. S. CUSTOMARY TO METRIC (SI)

UNITS OF MEASUREMENT . . . . . . . . . . . . . . . 3

PART I: INTRODUCTION . . . . . . . . . . . . . . . . . . 4

Background, Purpose, and Scope of Study . . . . . . . 4

Site Description ................ . . . . . . 4

Test Program ..................... 4

Equipment and Test Procedure . . . . . . . . . . 7

PART II: MAIN DAM TEST RESULTS . . . . . . . . . . . . 11

Seismic Tests Conducted . . . . . . . . . . . . 11

Data Interpretation - Main Dam . . . . . . . . . 12

PART III: AUXILIARY DAM TEST RESULTS . . . . . . . . . . 14

Seismic Tests Conducted . . . . . . . . . . . . 14

Data Interpretation - Auxiliary Dam . . . . . . . . 15

PART IV: CONCLUSIONS

Main Dam . . . . . . . . . . . . . . 18

Auxiliary Dam . . . . . . . . . . . . . 18

PLATES $1-26$ 


\section{CONVERSION FACTORS, U. S. CUSTOMARY TO METRIC (SI) \\ UNITS OF MEASUREMENT}

U. S. customary units of measurement used in this report can be converted to metric (SI) units as follows:

Multiply
feet
feet per second
inches per second
miles
pounds (mass)

$\frac{\text { By }}{0.3048}$
0.3048
0.0254
1.609344
0.4535924

To Obtain
metres
metres per second
metres per second
kilometres
kilograms.




\section{IN SITU SEISMIC INVESTIGATION, ISABELLA PROJECT, CALIFORNIA}

\section{PART I: INTRODUCTION}

\section{Background, Purpose, and Scope of Study}

1. Current seismic analysis procedures for earth dams and foundations require values of compression- and shear-wave ( $\mathrm{P}$ - and $\mathrm{S}$-wave) propagation velocities as a function of depth for program input. An in situ seismic investigation uses a suite of geophysical tests to determine $\mathrm{P}$ - and S-wave velocities and velocity zones. These are used in conjunction with conventional field sampling and laboratory testing to provide soil property information for an earthquake analysis of the dam and its foundation.

2. To accomplish such an analysis, a geophysical investigation was conducted at the Isabella Project which is located on the Kern River about 45 miles* northeast of Bakersfield, California, as shown in Plate 1. Since the Isabella Project consists of a main dam and an auxiliary dam, investigations were conducted at each embankment to determine $\mathrm{P}$ - and S-wave velocities as a function of depth within each dam and in underlying foundation materials.

\section{Site Description}

3. The main dam is an earthfill structure with a erest length of $1695 \mathrm{ft}$, a crown width of $20 \mathrm{ft}$, and a maximum height of $185 \mathrm{ft} . * *$ Its construction was completed in April, 1953. The dam has a central impervious core, a random fill shell section, and a horizontal drainage section that was placed on alluvium and founded on bedrock. The

A table of factors for converting U. S. customary units of measurement to metric (SI) units is presented on page 3.

** "Isabella Foundation Report," 1953, U. S. Army Engineer District, Sacramento, CE, Sacramento, Calif. 
spillway for Lake Isabella is located near the eastern end of the embankment. A plan view of the main dam is given in Plate 2. Transverse and longitudinal cross sections of the main dam are shown in Plate 3.

4. The auxiliary dam, located with respect to the main dam as shown in Plate 1 , is an earthfill structure with a crest length of $3257 \mathrm{ft}$, a crown width of $20 \mathrm{ft}$, and a maximum height of $100 \mathrm{ft}$. The westernmost $450 \mathrm{ft}$ of the embankment are constructed on the Kern Canyon Fault Zone. Foundation materials consist primarily of unstratified clayey, silty, or gravelly sands underlain by granite. An interesting feature of the auxiliary dam is its two-stage construction. Stage one, completed in 1948, included construction of an unzoned impervious fill embankment to a maximum elevation of $2617 \mathrm{ft}$ from sta $50+10$ to $60+40$, and from sta $64+25$ to $82+70$ measured at the embankment toe. Stage two, completed in 1953, consisted of constructing the Borel Canal realignment, broadening the upstream base, filling the center section (sta $60+40$ to $64+25$ ), and raising the embankment crest to el $2633.5 \mathrm{ft}$. Plates 4 and 5 give a plan view, transverse and longitudinal cross section, respectively, of the auxiliary dam.

\section{Test Program}

5. After a preliminary geophysical test program had been planned by Sacramento District personnel, it was submitted to U. S. Army Engineer Waterways Experiment Station (WES) for review. Pertinent information** relative to the design and construction of the dams was also provided to aid in the review. On 2 March 1977, an on-site-visit by WES and Sacramento District personnel was made at which time the actual test plan was formulated and test locations established.t The finalized test program consisted of surface refraction seismic, downhole, and

* All elevations (el) cited herein are in feet referred to mean sea level (msl).

* Isabella Office Report, Appendix 1, 6. January 1977, U. S. Army Engineer District, Sacramento, CE, Sacramento, Calif.

+ It will be noted that WES personnel will also consult and assist in the earthquake analyses of the dams. 
the geophysical data needed for an analysis of earthquake effects on the dam. The locations for these tests at both the main dam and the auxiliary dam are shown in Plates 2 and 4, respectively. Main dam

6. Surface refraction seismic tests at the main dam consisted of four traverses (forward and reverse on each of two lines). The orientation and location of the refraction seismic lines are shown in Plate 2. Line RS-l was approximately $1200 \mathrm{ft}$ long and was run along the crest of the embankment. Line RS-2 was approximately $275 \mathrm{ft}$ long and was run parallel to the longitudinal axis of the dam near the downstream toe.

7. Crosshole tests at the main dam (Plates 2 and 3 ) were conducted in boreholes $\mathrm{MD}-1$ and 2 on the downstream side of the embankment near sta 8+50 beginning at el 2513.5, which is $120 \mathrm{ft}$ below the crest of the main dam. The downhole test was conducted in borehole $\mathrm{MD}-1$. This location was selected for the crosshole and downhole tests because the alluvium underlying the horizontal drainage layer may be a concern in the dynamic analysis of the dam.*

Auxiliary dam

8. Surface refraction seismic tests at the auxiliary dam consisted of six traverses (three lines), the orientation and location of which are shown in Plate 4. Line RS-3 was approximately 1200 ft long and was run along the crest of the dam. Lines RS-4 and RS-5 were run essentially parallel to the embankment crest and were located near the upstream toe and downstream toe, respectively.

9. Crosshole tests were run in boreholes $A D-1,-2$, and -3 on the crest of the auxiliary das near sta 59+60 as shown in Plates 4 and 5. The downhole test was conducted in borehole $A D-3$. It will be noted that the borings passed through the interface produced by the two-stage construction of the dam and penetrated into bedrock.

10. The borings for the crosshole and downhole tests at both dams were made by WES personnel. The two borings at the main dam (MD-I and MD-2) were $15.5 \mathrm{ft}$ apart at the ground surface and positioned on a line

* Op. cit. Isabella Office Report. 
almost parallel to the axis of the dam--Borings $M D-1$ and $M D-2$ were drilled and cased with 3-in. I. D. plastic pipe to depths of 77 and $72 \mathrm{ft}$, respectively. The three borings at the auxiliary dam (AD-1 through $\mathrm{AD}-3$ ) were configured in a triangular pattern as shown in Plate 4. The distances along the ground surface from Boring AD-3 to $A D-1$ and $A D-2$ were 17 and $28.3 \mathrm{ft}$, respectively. Borings $A D-1,-2$, and -3 were drilled and cased with 3 -in I. D. plastic pipe to depths of 236 , 258, and $222 \mathrm{ft}$, respectively. The annular space between the casing and walls of that part of each boring in rock was grouted with a water and cement mixture. The remaining annular space (that in soil) was grouted with a mixture of Portland cement, bentonite, and water that had the consistency of soil. A borehole deviation survey was conducted by WES personnel to determine the precise vertical alignment of each hole. The reduction of data from the crosshole tests requires a knowledge of the drift of each borehole to determine the exact horizontal distance between boreholes at each depth tested.

\section{Equipment and Test Procedure}

\section{Surface refraction seismic tests}

11. These tests were performed using a portable battery-operated 24-channel refraction-reflection seismograph and oscillograph. The oscillograph produces a permanent record by converting a signal, in the form of electrical impulses, into a light beam response which is then recorded on light sensitive paper: Resolution time with the seismic unit is about $0.5 \mathrm{msec}$, depending on oscillograph speed setting and signal strength. Operation speed of the oscillograph was about 35 ips with timing lines displayed on the oscillogram at $10 \mathrm{msec}$ intervals. The seismic energy source was provided by the detonation of explosives (1-2 1b) in shotholes $10 \mathrm{ft}$ deep. Soil response was monitored by 24 vertical velocity-type transducers (geophones) placed in a straight line at selected intervals (25-50 ft) along the surface of the ground. Seismic lines requiring more than 24 geophones were divided into segments, since only 24 channels could be monitored at one time. Both 
forward and reverse traverses were run for each seismic line so that true velocities, in addition to apparent velocities, could be determined and depths to refracting interfaces computed.

Downhole tests

12. These tests, designed to provide data for determination of vertically oriented $\mathrm{P}$ - and S-wave velocities, were conducted using the same seismograph and recorder as those used for the refraction seismic tests. The geophone used to detect the transmitted signal consisted of a triaxial array of transducers housed in a unit having an integral extendable spring that assured sound contact with the plastic casing in the hole.

13. In practice, the receiver geophone was placed at a depth of $10 \mathrm{ft}$ in a borehole. A steel plate, positioned approximately 1 ft from the mouth of the boring on the ground surface, was given a vertical hammer blow to create the vertical $P$-wave source. A vertical velocitytype geophone adjacent to the hamer impact point provided zero time. S-wave determinations were then made by placing a large wooden plank on the ground surface and striking the plank. Successive blows were struck at each end in order to reverse polarity of the horizontally polarized shear wave thus facilitating identification. A horizontal velocity-type geophone provided zero time. The procedures for obtaining $\mathrm{P}$ - and S-wave data were then repeated with the receiver geophone at 10-ft increments of depth until the bottom of the borehole was reached. Data obtained from the downhole tests were plotted as time versus depth from the source to the receiver geophone. Average and incremental velocities can be determined from this type of plot.

Crosshole tests

14. In most instances, the crosshole technique is used in conjunction with surface refraction seismic surveys. The crosshole method is a straightforward way of determining horizontal velocities and layering, and has a distinct advantage over the conventional surface refraction method in that low velocity zones can be detected if they are sufficiently thick with respect to the source and receiver spacing.

15. Crosshole surveys are normally conducted by using two or more 
borings, cased or uncased, into which a seismic source and transducers are placed at known elevations. The spacing of borings and source elevations may be varied according to site-dependent conditions and sources, and geophones may be of various types in order to enhance S-wave arrival time determinations. $\mathrm{P}$-wave and S-wave measurements may be made by this procedure.

16. The crosshole tests discussed herein were conducted using the same seismograph and recorder that were used for the refraction seismic tests. The crosshole procedure was a modified technique that used the same vibratory source and control package as that described by Ballard.* The primary difference in the two procedures was concerned with the data acquisition package, i.e., no signal enhancement was used. Rather, the vibratory source was swept through a frequency range while monitoring the output of the two geophones in the receiver boreholes. When an acceptable response was received at a specific frequency, this frequency was then interrupted by a tone burst generator to send a specific number of cycles of energy at that frequency to the receiver unit(s). The source geophone was displayed simultaneously along with both receiver geophones on the oscillograph. By so doing, the origination of the source pulse could easily be recognized, and the time difference between that pulse and the signal arrival receiver(s) could be determined. In most cases the frequency which propagated well at the dams were between 100 and $200 \mathrm{~Hz}$. Accuracy associated with this test procedure and instrumentation is on the order of approximately $0.5 \mathrm{msec}$.

17. In practice, the tests were conducted by first placing the source and receiver(s) at the same depth (10 ft) near the top of the boreholes, then pulsing the source unit several times recording both transmitted and received signals. After a satisfactory record had been obtained, the units were then repositioned $10 \mathrm{ft}$ deeper. The procedure above was repeated at this and each succeeding 10-ft depth down to $180 \mathrm{ft}$. Below $180 \mathrm{ft}, \mathrm{S}$ arrival time intervals could not be determined

R. F. Ballard, Jr., "A Method for Crosshole Seismic Testing," Journal of Geotechnical Engineering Division, American Society of Civil Engineers, Vol. 102, GT12, Dec. 1976, pp 1261-1273. 
from the data obtained using the vibrator; therefore, exploding bridgewire detonators (EBW's) were employed. The S-wave arrival times were obtained from the resulting records.

18. The P-wave data were obtained using the same procedure described above, except that the vibrator and its associated instrumentation were not employed as the signal source. Instead, the EBW's were used at each 10-ft increment as the P-wave source. .

19. Data obtained from the crosshole tests were the increments of time required for $P$ - and $S$-waves to propagate from the source to a point of detection. These times were then divided into the distance between source and receiver geophone(s) to provide apparent velocities. If a nearby higher velocity layer exists, the wave will refract and travel along that layer, thus traveling along a faster path than the direct distance path. Since this occurred at both dams, calculations based on Snell's. law of refraction were used to determine true velocities by accounting for zones of high velocity contrast. Due to the nature and number of calculations involved in a typical application of the crosshole technique to a layered site, a computer program for crosshole seismic interpretation was used for data reduction. This program applies Snell's law to develop a plausible true velocity interpretation from the apparent velocity obtained in the field. 


\section{Seismic Tests Conducted}

\section{Surface refraction tests}

20. The data presented in the time versus distance plot shown in Plate 6 were collected from refraction seismic lines RS-1 on the main dam crest. Four velocity zones were indicated. The first zone extended to depths of 10 to $13 \mathrm{ft}$ below the dam crest and had an average velocity of 1,750 fps.* The underlying zone, ranging from 78 to $90 \mathrm{ft}$ in depth exhibited a true velocity of 2,550 fps. Zone 3 had a true velocity of 8,050 fps to a depth of $224 \mathrm{ft}$ where the fourth zone with a true velocity of 18,450 fps was encountered.

21. Data collected from refraction seismic line RS-2 near the downstream toe of the main dam are presented in the time versus distance plot shown in Plate 7. The delayed arrival times at distances of 25, 50, and 75 ft from the west end of line RS-2 probably indicated a local depression in the rock surface filled with slower velocity soil. Only two velocity zones were present. The first zone was 10 to $13 \mathrm{ft}$ deep and had an average velocity of 2,600 fps. Underlying the above zone was a layer with a true velocity of 15,350 fps.

\section{Downhole Tests}

22. Three P-wave velocity zones were determined from the downhole test at the main dam as shown in Plate 8. Zone 1, with an average velocity of 2,150 fps, extended to a depth of $47 \mathrm{ft}$. The second zone extended from a depth of 47 ft to $60 \mathrm{ft}$ and had an average velocity of 3,850 fps. A third zone with an average P-wave velocity of 14,600 fps began at a depth of $60 \mathrm{ft}$ and extended to $77 \mathrm{ft}$, which was the limit of the borehole.

23. Plate 8 also shows three S-wave zones determined from the downhole test. These zones had average velocities of 1000, 1400, and

For the purpose of developing idealized profiles in this report, Pand $S$-wave velocities for the various zones have been rounded to the nearest $50 \mathrm{fps}$. 
4850 fps with associated interfaces at 15- and 60-ft depths. Crosshole test

24. The crosshole P-wave test indicated the presence of three velocity zones as shown in Plate 9. Zone 1 extended to a depth of $20 \mathrm{ft}$ and had a true velocity of 1,800 fps. The second zone, which began at a depth of $20 \mathrm{ft}$ and continued to a depth of $60 \mathrm{ft}$, had a true velocity of 3,650 fps. Zone 3 began at a depth of $60 \mathrm{ft}$ and exhibited a true velocity of 18,750 fps.

25. Three velocity zones were also indicated by the crosshole S-wave tests as shown in Plate 10. The first zone was $20 \mathrm{ft}$ deep and had a true velocity of 950 fps. Zone 2, with a true velocity of 1,250 fps, extended from the 20- to 60-ft depths. A velocity of 4,550 fps was indicated for Zone 3 which began at a depth of $60 \mathrm{ft}$.

\section{Data Interpretation - Main Dam}

\section{P-wave velocities}

26. Plate 11 shows results from the crosshole, downhole, and downstream refraction seismic tests. These are in good general agreement with the only discrepancy being the excessive thickness of Zone 1 given by the downhole test. The discrepancy between the downhole and crosshole tests may be attributed to poor quality data from the downhole test caused by the loose riprap near the surface at the site of test borings.

27. Refraction seismic line RS-l results are in good agreement with the other tests after known subsurface conditions are considered. Plate 2 shows the location of line RS-l on the main dam crest. Plate 3 shows traverse and longitudinal cross sections of the main dam which are helpful in proper interpretation of the data from line RS-1. Plate 12 presents the interpreted velocity zones at Section A-A close to the western end of line RS-1. Zone 1, with a velocity of 1,750 fps, correlates with a layer of fill material on top of the central impervious core. The core and Zone $2(2,550 \mathrm{fps})$ also correlate well. The interface between Zones 2 and 3 correlates well with the rock line beneath 
the shot points on each end of the line as shown on the longitudinal cross section in Plate 3. The third zone, with a velocity of 8,050 fps, appears to be a thick layer of weathered granite followed by fresher granite in Zone 4 which had a P-wave velocity of 18,450 fps.

28. The crosshole and downhole results depicted in Plate il were analyzed and interpreted that there are three $P$-wave velocity zones at Section B-B as shown in the profile, Plate 13. The near-surface zone averaged 2,000 fps to a depth of $20 \mathrm{ft}$. The underlying zone exhibited an average velocity of 3,750 fps to a depth of $60 \mathrm{ft}$ where granite was encountered with a velocity of 16,700 fps. It will be noted that the horizontal drainage blanket and the alluvium under it (50 to $60 \mathrm{ft}$ depth \pm ) are encompassed in the second velocity zone and therefore, the 3,750 fps is applicable for the velocity of the alluvium.

S-wave velocities

29. Results obtained from the crosshole and downhole tests at the main dam are in good agreement, as shown in Plate 14. The interpretation for these results are presented in Plate 15. Three velocity zones are indicated. The first zone had an average S-wave velocity of 950 fps to a depth of $17 \mathrm{ft}$. Zone 2 extends from a depth of $17 \mathrm{ft}$ to $60 \mathrm{ft}$ and exhibited an average velocity of $1300 \mathrm{fps}$. It will be noted that the horizontal drainage blanket and the alluvium under it (50- to 60- ft depth) are encompassed in Zone 2 and therefore, have a velocity of $1300 \mathrm{fps}$. The third zone, with an average S-wave velocity of $4700 \mathrm{fps}$, began at a depth of about $60 \mathrm{ft}$. Plate 15 shows section B-B with the interpreted average velocity zones for all S-wave tests conducted at the main dam. As mentioned above, the 1300 fps velocity is applicable for the alluvium. 


\section{PART III: AUXILIARY DAM TEST RESULTS}

\section{Seismic Tests Conducted}

\section{Surface refraction tests}

30. As mentioned previously, three refraction seismic lines (RS-3 through RS-5) were run at the auxiliary dam. The time versus distance plots for the lines are shown in Plates 16-18. Also presented in these plates are true and apparent velocities and depths to interfaces.

31. Test results from line RS-3 (Plate 16), which was run along the dam crest, yielded three P-wave velocity zones. The first velocity zone averaged 2,450 fps to depths ranging from 88 to 109 ft below the dam crest. The second velocity zone had a true velocity of 7,300 fps and extended to depths varying from 183 to $239 \mathrm{ft}$ beneath the crest of the dam where a true velocity of 11,750 fps was encountered.

32. The results from seismic line RS-4 (Plate 17), located near the upstream toe, indicated three velocity zones. The near-surface material averaged 3,200 fps to depths of $11-13 \mathrm{ft}$. The underlying zone exhibited a true velocity of 6,100 fps to varying depths of 118-122 ft. The third zone had a true velocity of 12,950 fps and was detected at the 118- to 122-ft-depth ranges.

33. Seismic line RS-5 results (Plate 18 ), determined near the downstream toe, also indicated three velocity zones. The near surface had a velocity of 2,800 fps to depths ranging from $10 \mathrm{ft}$ to $2 \mathrm{ft.}$. The underlying zone exhibited a true velocity of 6,500 fps and extended to depths varying from 150 to 160 ft where a 12,250 fps velocity was encountered for a third zone.

Downhole test

34. The results of the downhole test are shown in Plate 19. Three $\mathrm{P}$-wave and two S-wave velocity zones were exhibited. Average vertical $P$-wave velocity for the near-surface material was 1600 fps to a depth of about $18 \mathrm{ft}$. The second zone had a velocity of $3550 \mathrm{fps}$ to a depth of $115 \mathrm{ft}$ and was underlain by a $6700 \mathrm{fps}$ velocity which extended at least to a 200-ft depth, the limit of data. Average vertical S-wave 
velocities were 1100 fps to a depth of $40 \mathrm{ft}$ and 1550 fps from 40- to at least the 170-ft depth, the limit of valid data. Crosshole tests

35. The crosshole tests were conducted using Boring $A D-3$ as the seismic source borehole and Borings $A D-1$ and -2 as receiver holes. The P-wave velocity results from the crosshole test are shown in Plate 20 alongside the receiver locations. It will be noted that only one P-wave velocity is shown for each test elevation although true P-wave velocities were determined from the seismic source borehole to each of the receiver boreholes. In comparing the velocities from the source to each receiver, the spread was so narrow that it was thought advantageous to average the two velocities at each elevation. In so doing, maximum error was less than 5 percent. This small percent error which is established by the redundancy incorporated into the test program, builds a high level of confidence in the data obtained.

36. As shown in Plate 20, the P-wave velocities generally increase with depth from a low of 2,450 fps near the surface to 13,400 fps at a depth of $220 \mathrm{ft}$.

37. The S-wave velocity results are presented in Plate 21 alongside the receiver locations. As was done with the P-wave velocities, the S-wave velocities determined from source hole to receiver holes were averaged for each test elevation. S-wave velocities, as shown, generally increase with depth from a low of 1000 fps near the surface to 3750 fps at about 210 ft deep.

\section{Data Interpretation - Auxiliary Dam}

38. The P-wave velocity results from the crosshole, downhole, and surface refraction tests conducted at the auxiliary dam have been condensed into a composite of results (Plate 22). This composite was analyzed and an interpretation made which produced three velocity zones, as shown in the profile (Plate 23). Laboratory classifications obtained from field samples are also presented in the plate. The first velocity zone averaged $2850 \mathrm{fps}$ and extended from the crest of the dam 
(el 2633) to the dam foundation (el 2533). The second velocity zone exhibited an average velocity of 6,600 fps from el 2533 to about el 2433. This zone correlates well with the foundation materials, which are predominately clayey sand. The third velocity zone averaged 12,100 fps and was detected at elevations ranging from 2437 to 2407 . Correlation of the top of this zone with the top of rock (fractured granite) is excellent.

39. The S-wave velocity results from the crosshole and downhole tests were also composited and are depicted in Plate 24. The composite of results was analyzed and interpreted to indicate the existance of three velocity zones, as shown in the profile (Plate 25). Laboratory classification of the materials is also presented in the plate. An average velocity of 1150 fps was interpreted for the first zone which extended from el 2633 to about el 2583. Underlying this velocity zone was a 1600-fps layer that extended to el 2439. The change in S-wave velocity (1150 to 1600 fps) for the dam proper could be due to the increased overburden pressures with depth. The third velocity zone detected at el 2439 exhibited an average velocity of $3300 \mathrm{fps}$ and is indicative of the rock (fractured granite) noted from the boring data.

40. An alternate $\mathrm{P}$ - and $\mathrm{S}$-wave velocity profile interpretation is presented in Plate 26 using finer zoning. This interpretation is based on profiling the crosshole velocities and is applicable to the embankment and foundation of the dam. Based on the discussion on repeatability in paragraph 35, this fine zoning is believed valid at the location of the crosshole investigation borings.

41. Referring to Plate 26, which also has applicable laboratory classification data superimposed, the interpreted $\mathrm{P}-$ and S-wave velocity zones generally exhibit an increasing trend with depth. The zones range from a low of $2,450 \mathrm{fps}$ (P-wave) and 1,000 fps (S-wave) for the nearsurface material to a high of $13,400 \mathrm{fps}$ (P-wave) and 3,750 fps (S-wave) for granite at a depth of $220 \mathrm{ft}$. Prominent features include:

a. A 2600-rps.P-wave velocity lense at el 2583 that is bounded above and below by higher velocity material.

b. A 1950-fps S-wave zone that is interpreted as a high velocity lense. 
c. A 1400-1ps S-wave velocity zone from el 2463 to 2436 that underlies a higher velocity zone (1550 fps).

d. The 10,000-fps (P-wave) and 2,800-1ps (S-wave) zones correlate extremely well with the top of the granite layer.

42. The $P-$ and S-wave velocity interpretation presented in paragraphs 38 and 39 and depicted in Plates 23 and 25 is believed to be representative of the in situ values for the entire dam and its foundation. This interpretation is therefore recommended as input into the primary velocity dynamic analysis of the dam. The alternate interpretation (paragraphs 40 and 41 and Plate 26) may not be applicable for the entire dam and foundation, but is presented for use in the event the conditions shown do not exist for all the dam and foundation. It is recommended that the alternate interpretation also be addressed in the dynamic analysis phase of the project. 


\section{PART IV: CONCLUSIONS}

43. The following conclusions were drawn as a result of the in situ seismic investigation conducted at the Isabella main and auxiliary dam.

\section{Main Dam}

44. The interpretation of $\mathrm{P}$-wave velocity data at the main dam indicates four significant velocity zones. These four zones have velocities of $1,750,2,550,8,050$, and 18,450 fps which are associated with (a) fill material above the central impervious core, (b) the central impervious core, (c) weathered granite, and (d) fresh granite, respectively.

45. Velocity data for $\mathrm{P}$ - and $\mathrm{S}$-waves from crosshole and downhole tests on the downstream face of the main dam indicated three velocity zones. The first zone with velocities of 2,000 and 950 fps ( $P$ - and S-wave, respectively) was approximately $20 \mathrm{ft}$ thick. Zone 2 had velocities of 3,750 and 1,300 fps and extended to bedrock (granite) at a depth of $60 \mathrm{ft}$ from the surface. Zone 3 had $P$ - and S-wave velocities of 16,700 and 4,700 fps, respectively. The alluvium and horizontal drainage blanket at the 50- to 60-ft depth had $P$ - and S-wave velocities of 3,750 and 1,300 fps, respectively.

\section{Auxiliary Dam}

46. Both a primary and an alternate interpretation of the $P$ - and S-wave velocity data were made to aid in the analysis phase of the Isabella Project.

47. In the primary interpretation, three $\mathrm{P}$ - and $\mathrm{S}$-wave velocity zones were established. The P-wave zones were 2,850 fps for the embankment, 6,600 eps for the foundation materials to bedrock, and 12,100 fps for fractured granite. The S-wave zones were 1,150 fps for the upper $50 \mathrm{ft}$ of the embankment, 1,600 fps for the remainder 
of the embankment plus the foundation materials to bedrock, and 3,300 fps for fractured granite.

48. The alternate interpretation was based on profiling the crosshole velocities and provides much more detail about local seismic properties in the vicinity of the crosshole test borings. Nine P-wave and eight S-wave velocity zones were established by this interpretation. The zones ranged from a low of 2,450 fps ( $P$-wave) and 1,000 fps (S-wave) for the near-surface material to a high of $13,400 \mathrm{fps}$ (P-wave) and 3,750 fps (S-wave) for fractured granite at a depth of $220 \mathrm{ft}$. Prominent features of the alternate interpretation were a 2,600-fps P-wave velocity lense $50 \mathrm{ft}$ below the crest of the dam that was bounded above and below by higher velocity material, a 1,950-fps S-wave zone about $120 \mathrm{ft}$ below the crest that was interpreted as a high velocity lense, a 1,400-fps S-wave velocity zone that underlies a higher velocity zone (1,550 fps) at a depth of $170 \mathrm{ft}$ below the crest, and a 10,000-fps (P-wave) and 2,800-fps (S-wave) zone that correlated extremely well with granite noted at about $195 \mathrm{ft}$ below the dam crest. 


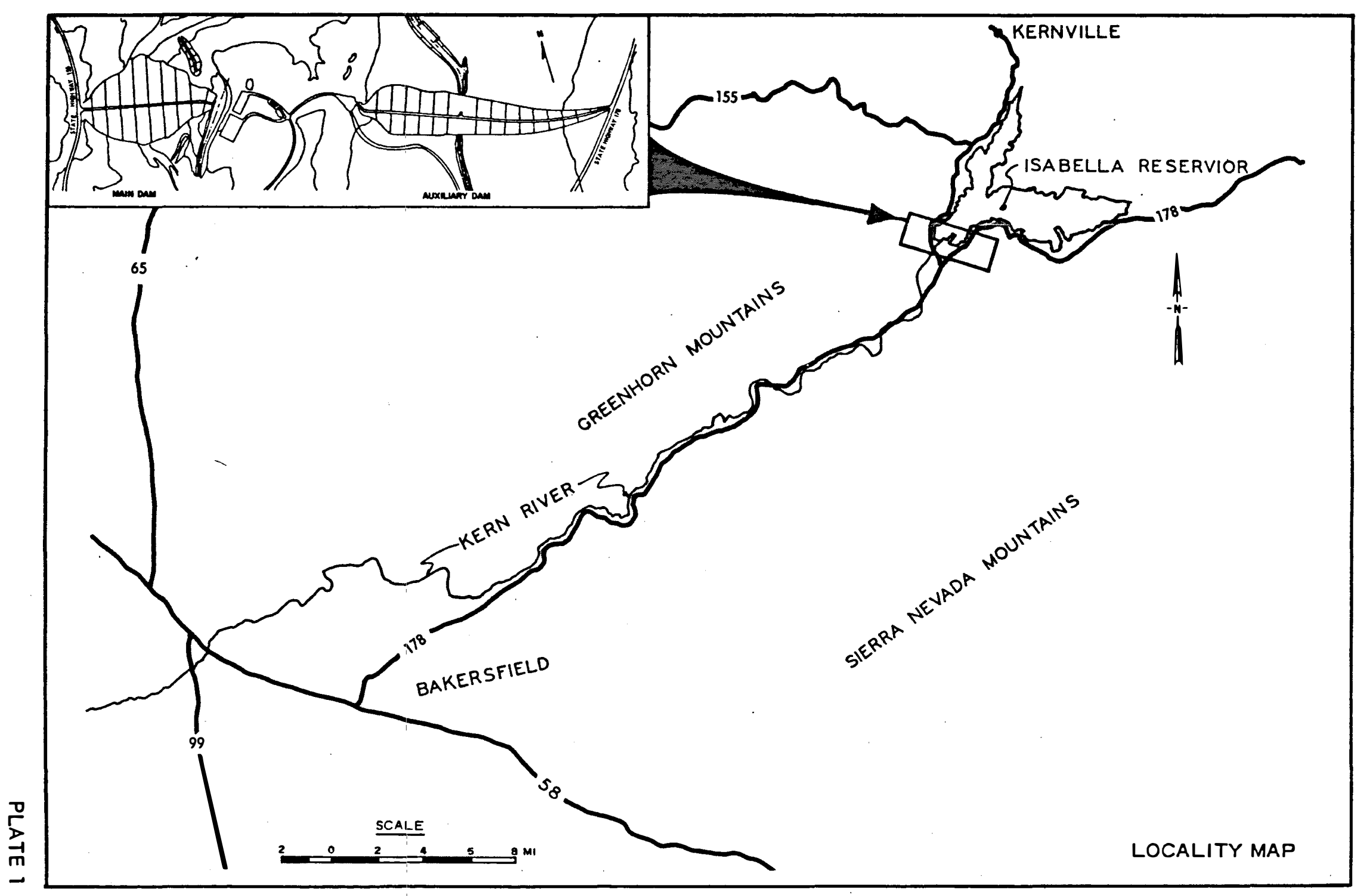




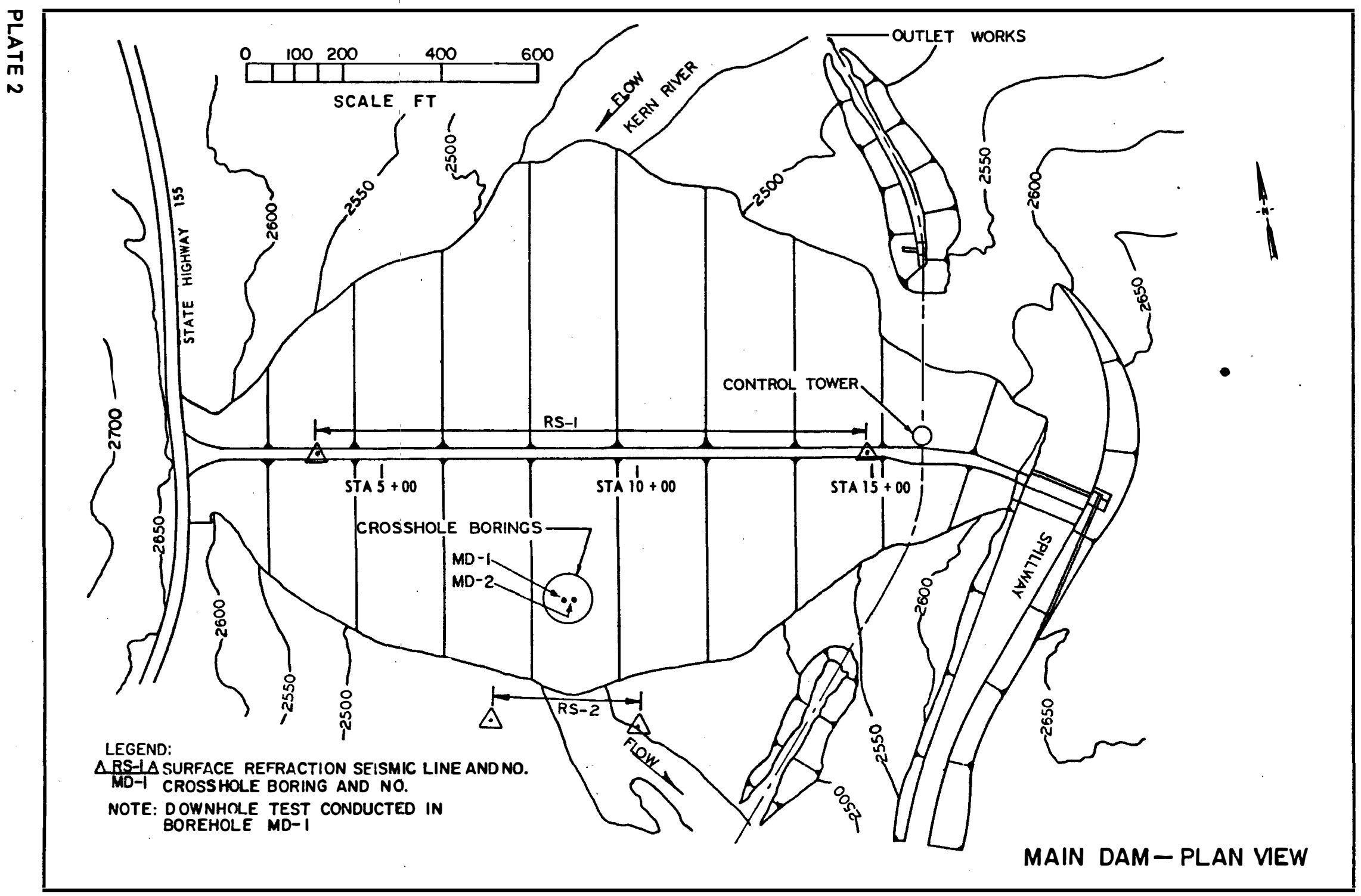




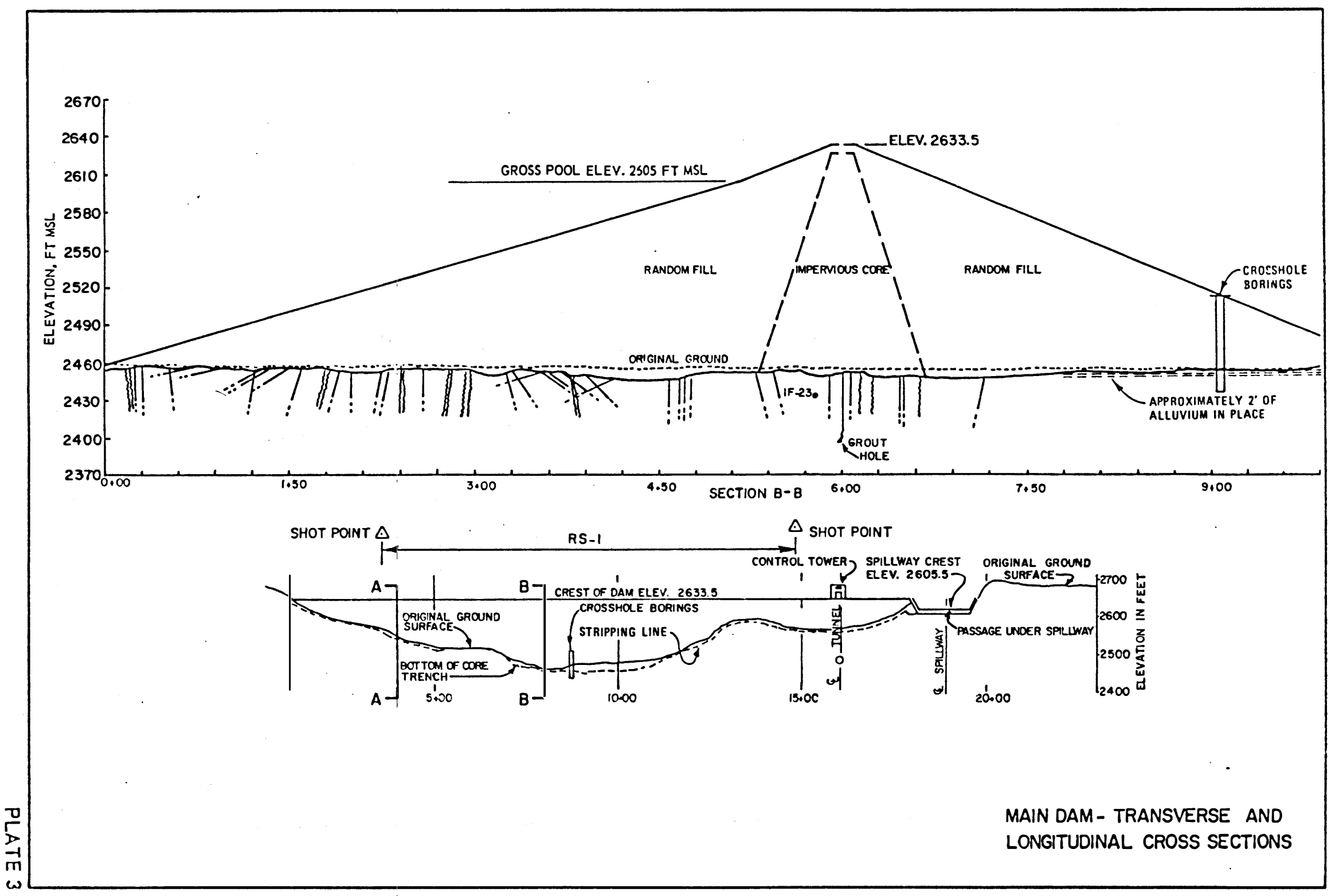




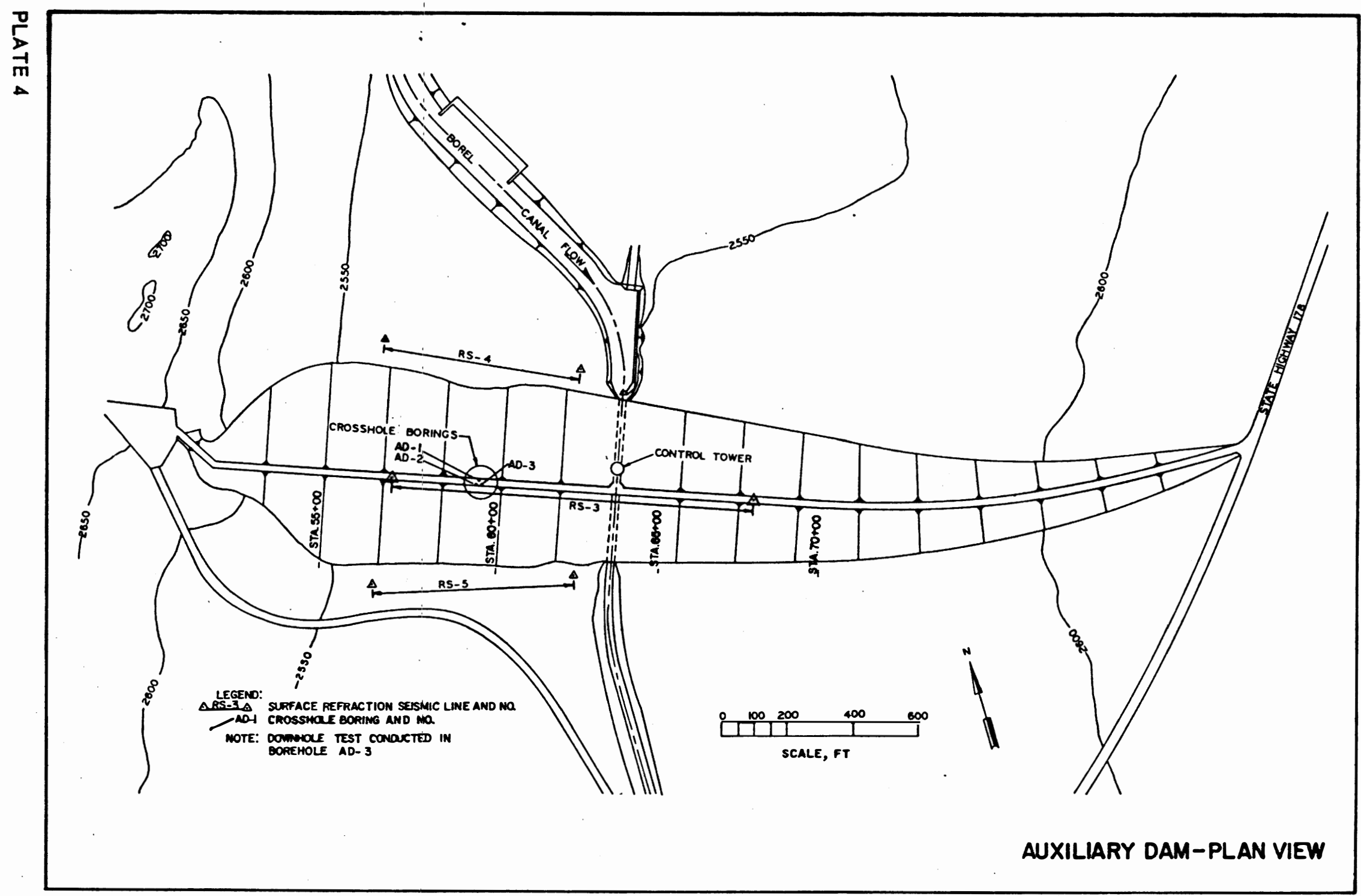




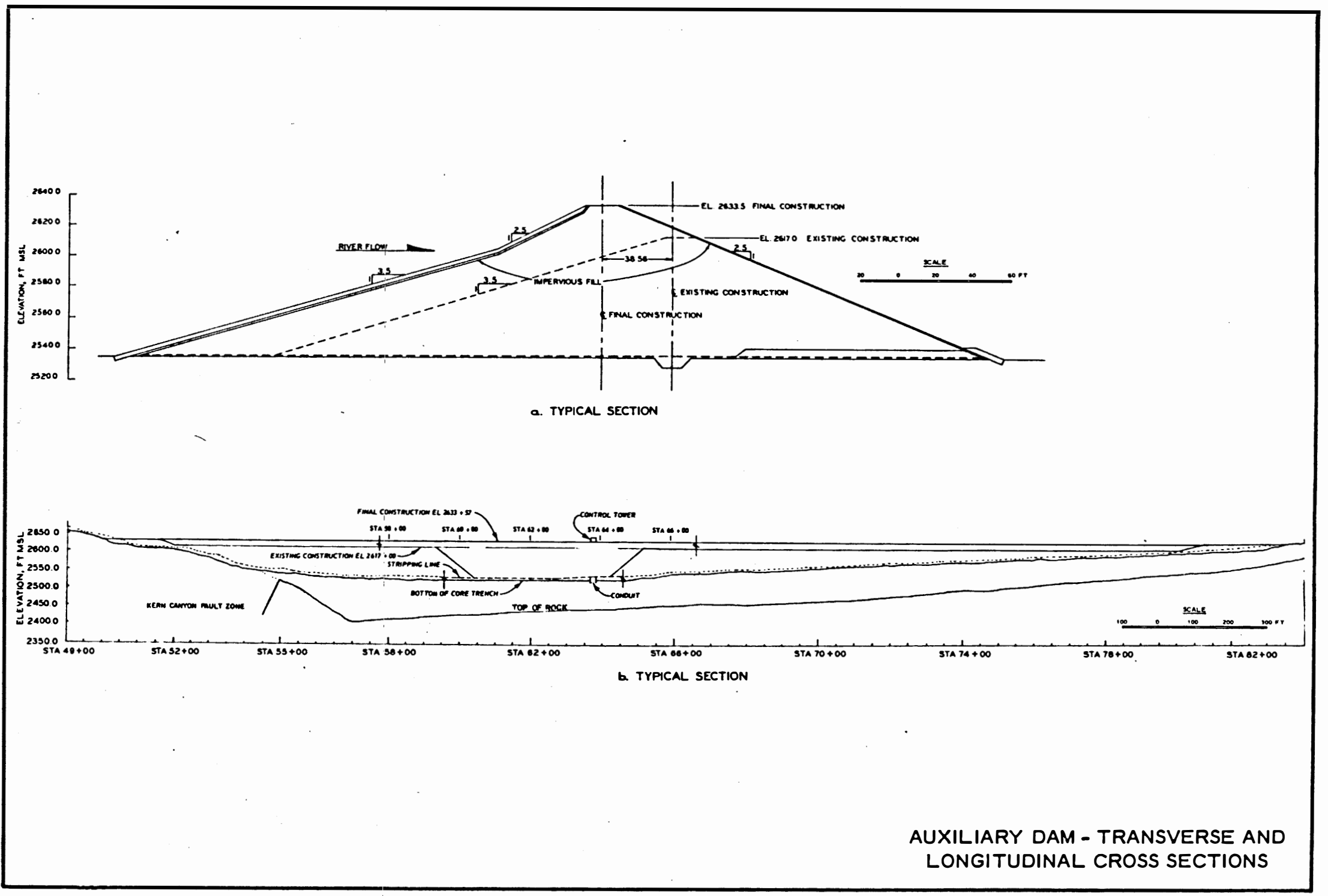




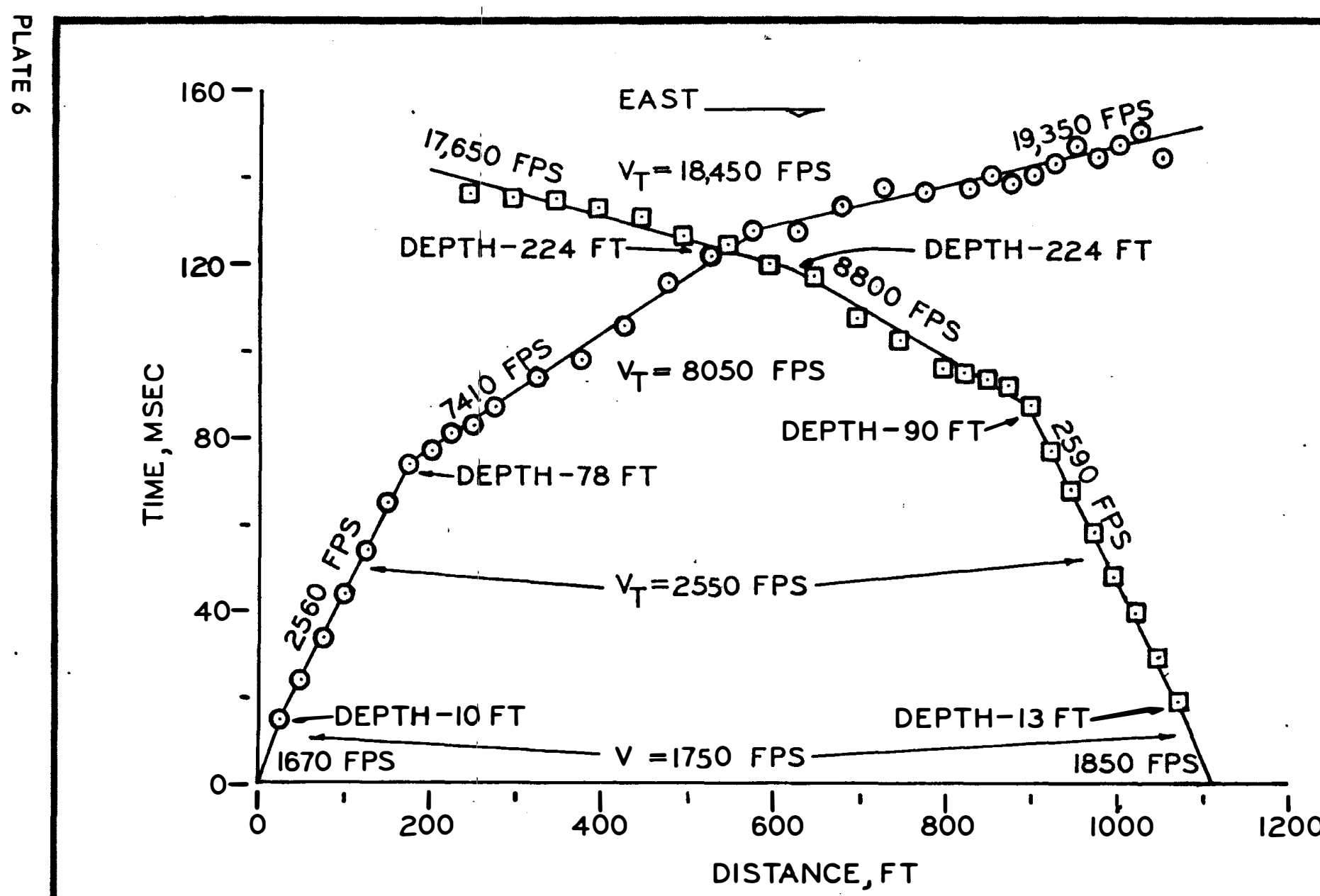

REFRACTION SEISMIC LINE RS-I ISABELLA PROJECT, CA 


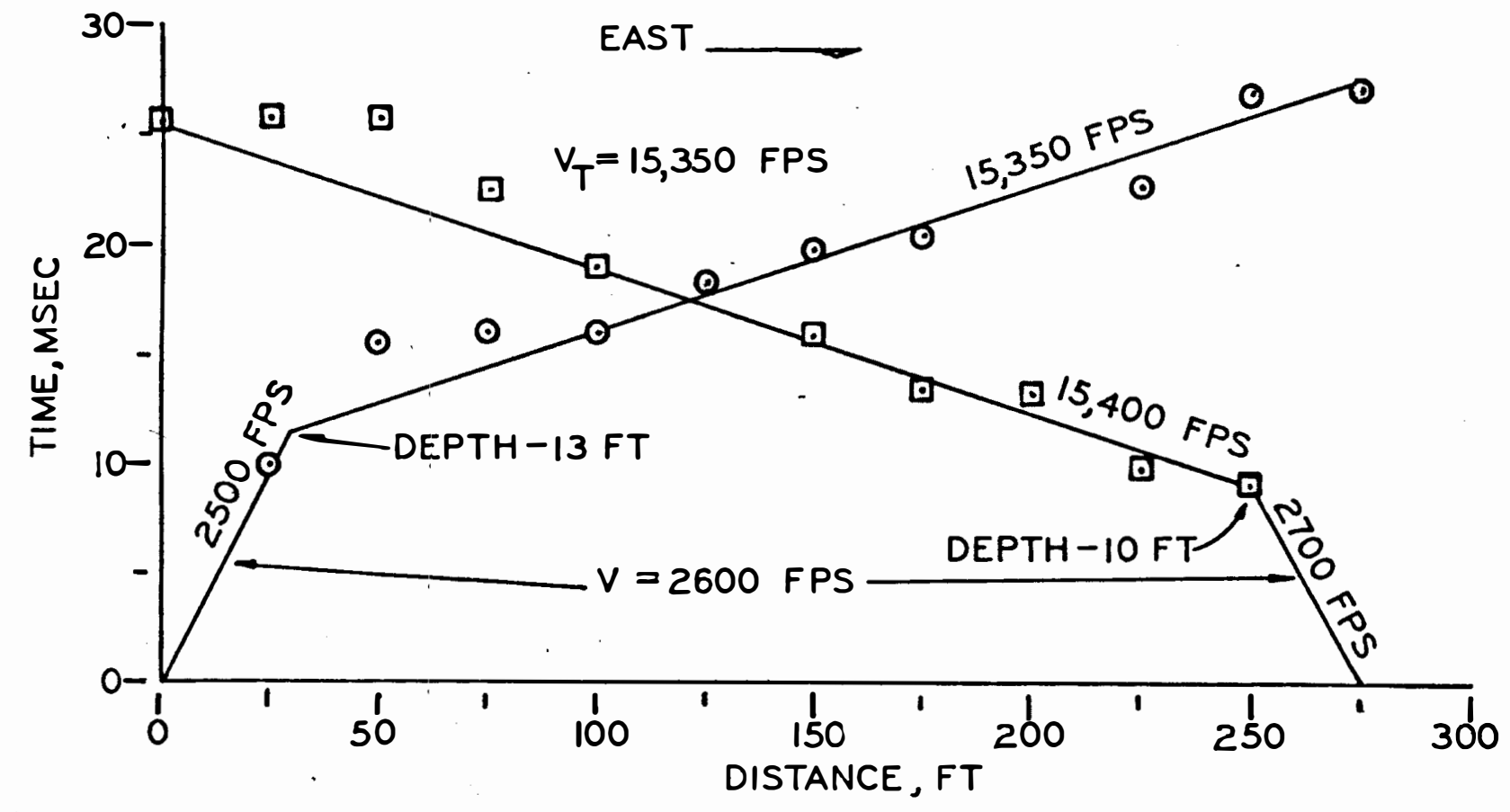

REFRACTION SEISMIC LINE RS-2 ISABELLA PROJECT, CA 


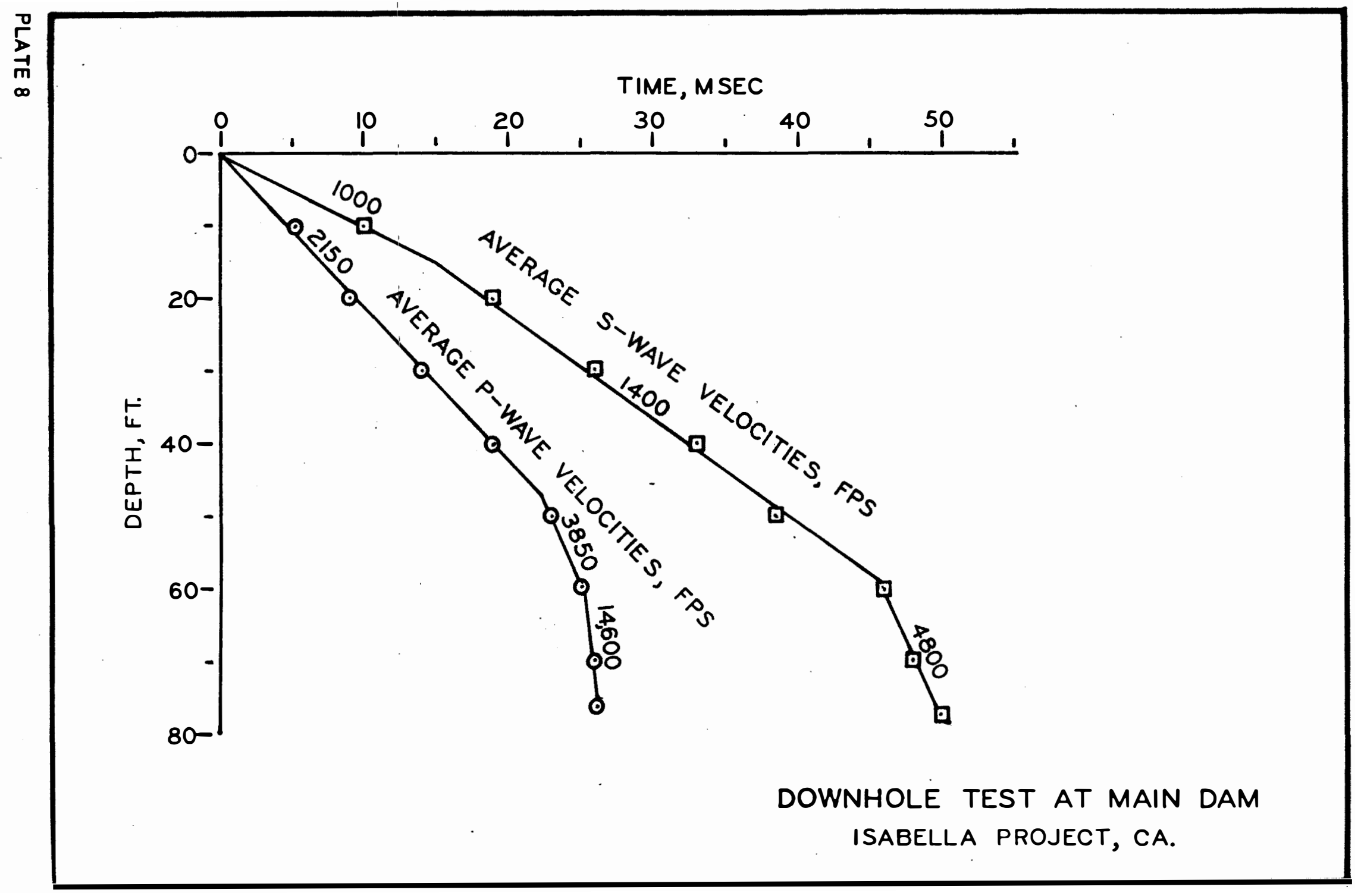




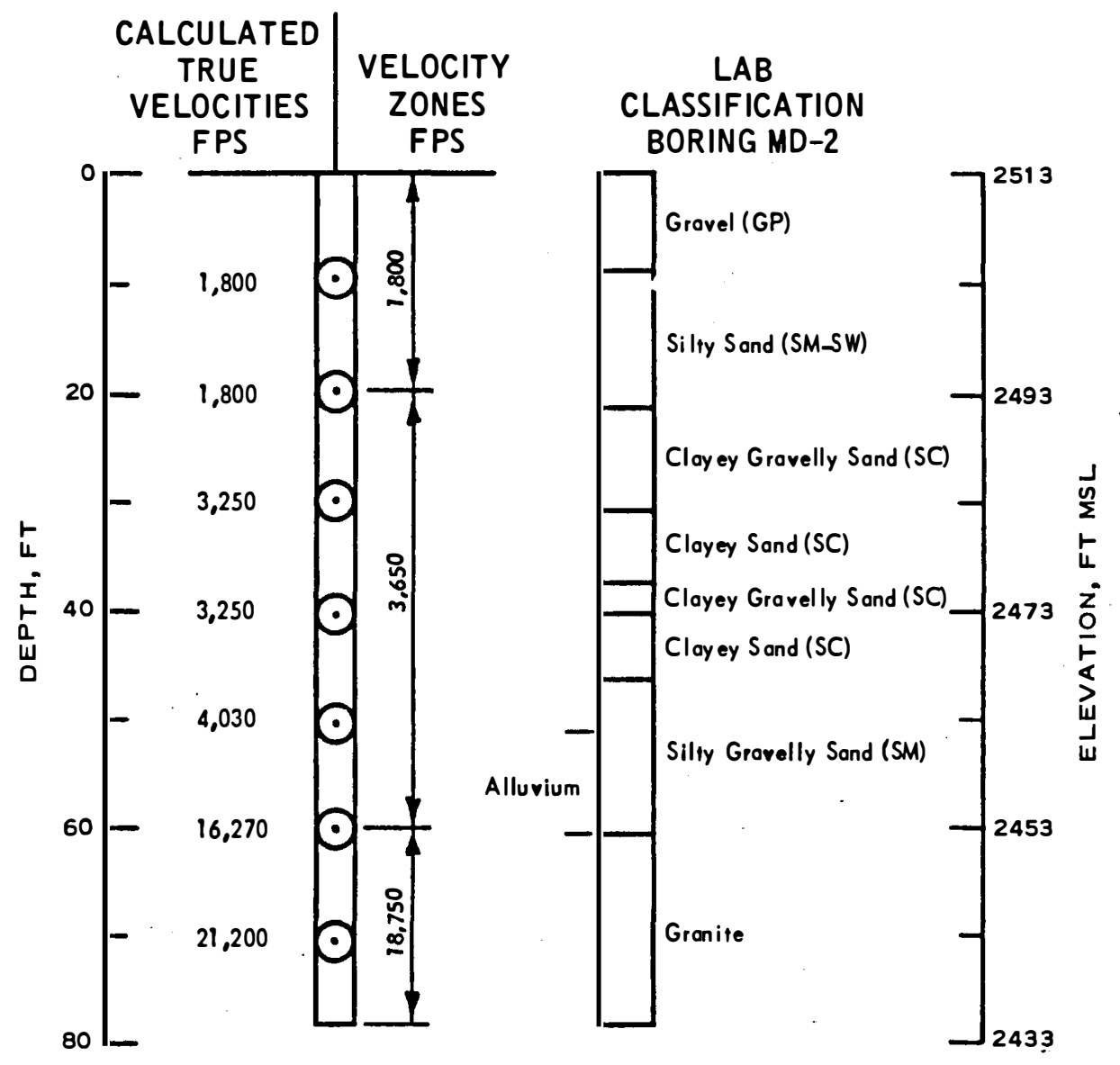

CROSSHOLE P-WAVE VELOCITIES MAIN DAM, ISA BELLA PROJECT, CA 


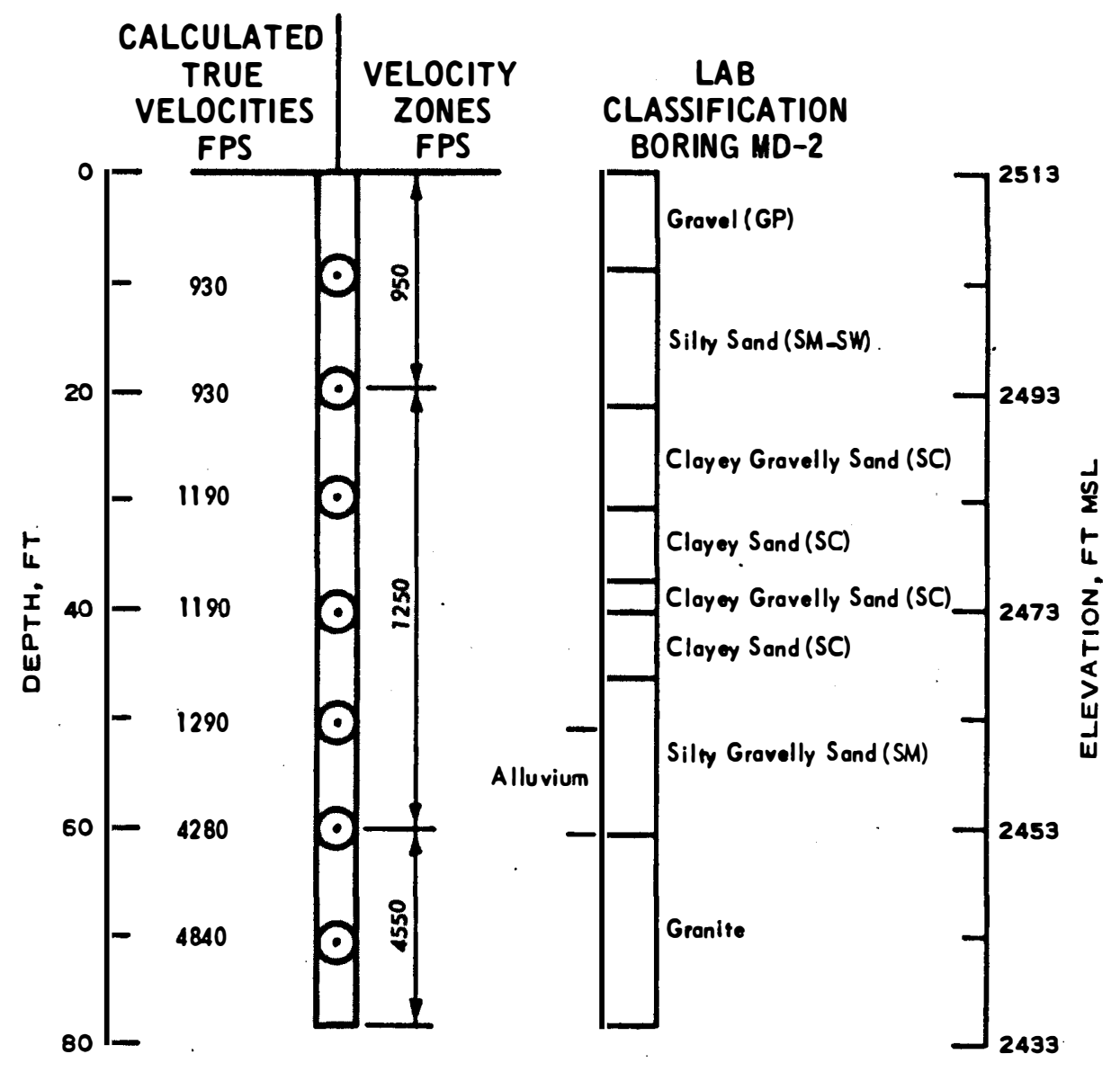




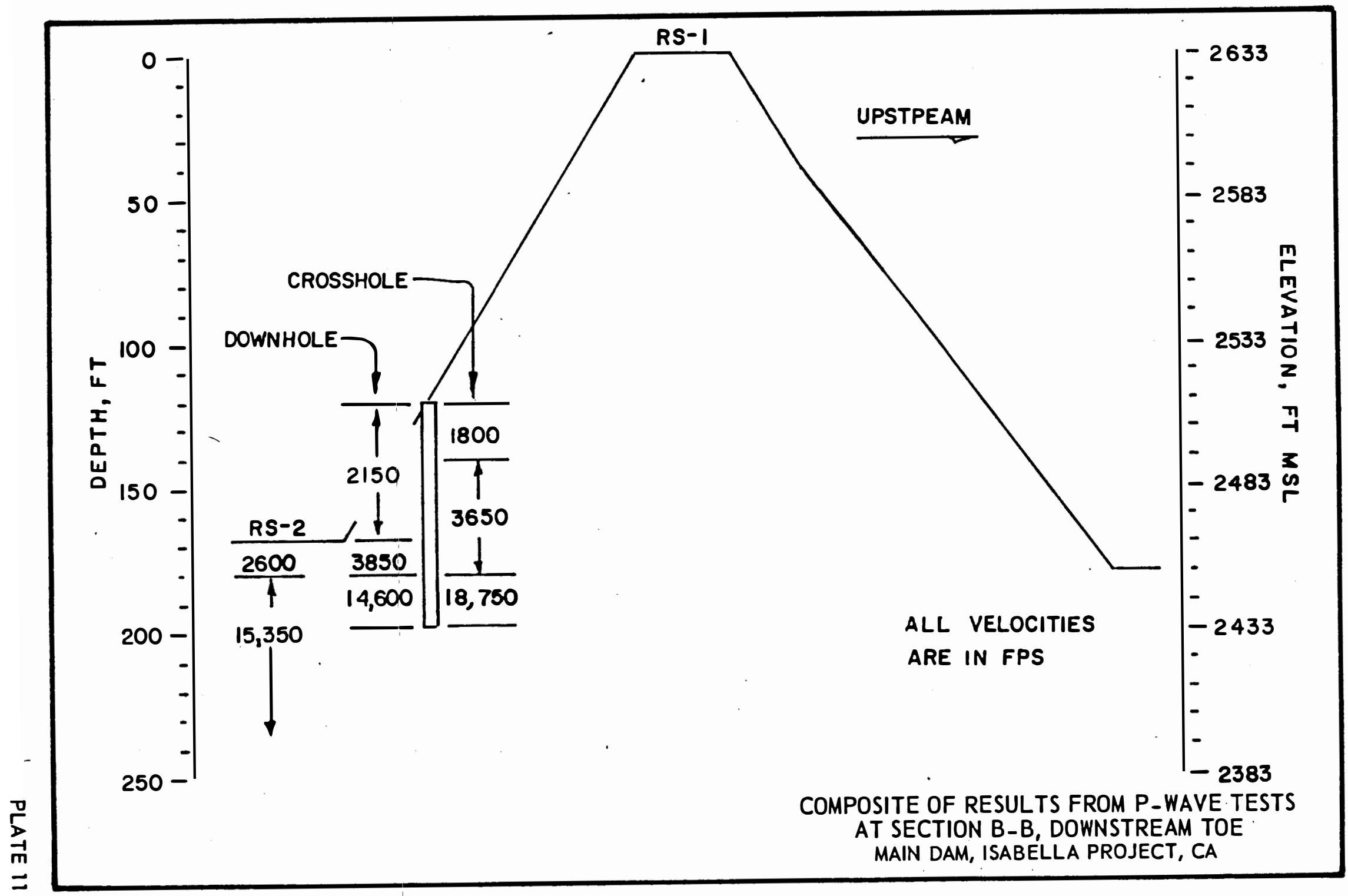




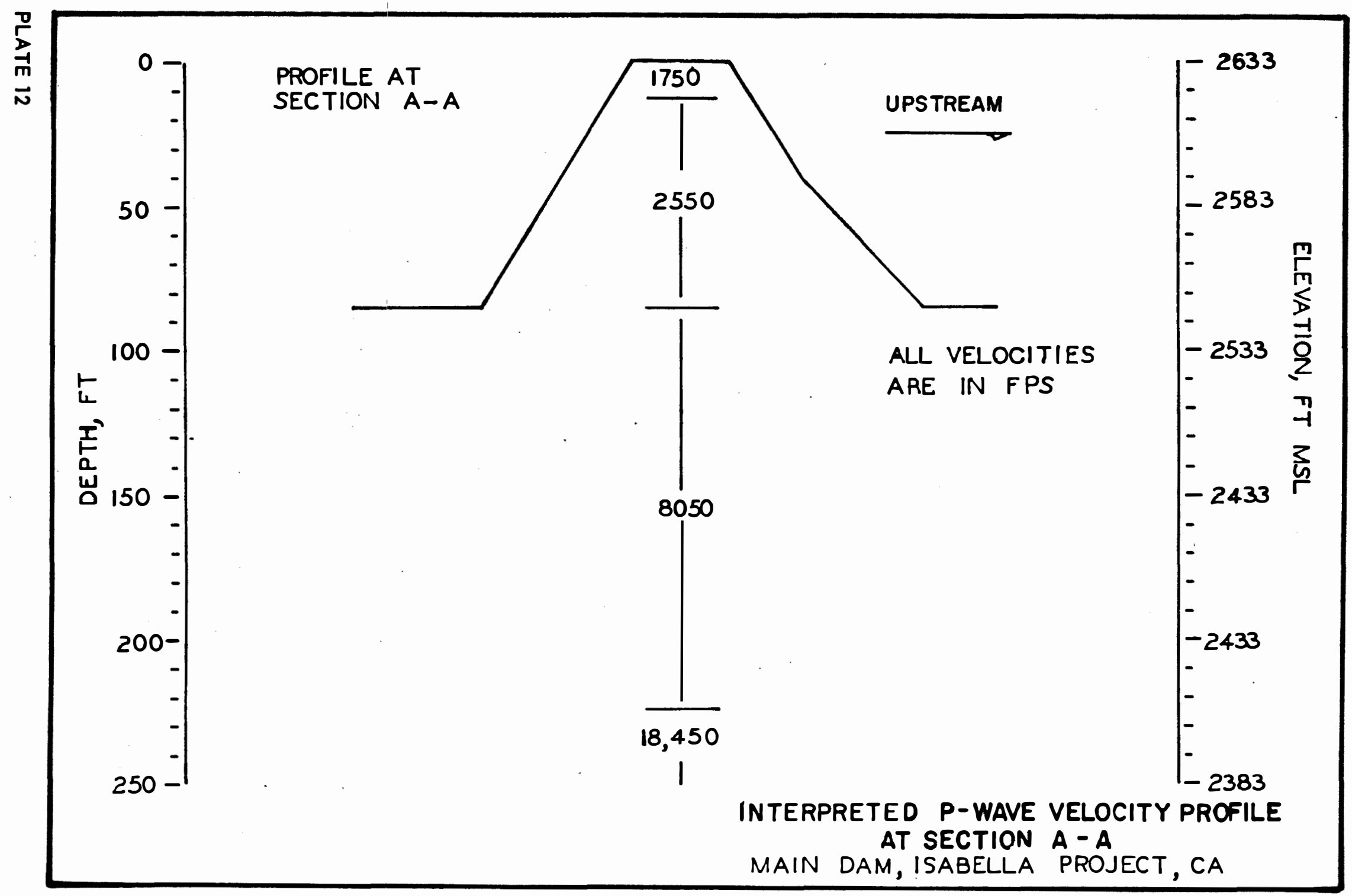




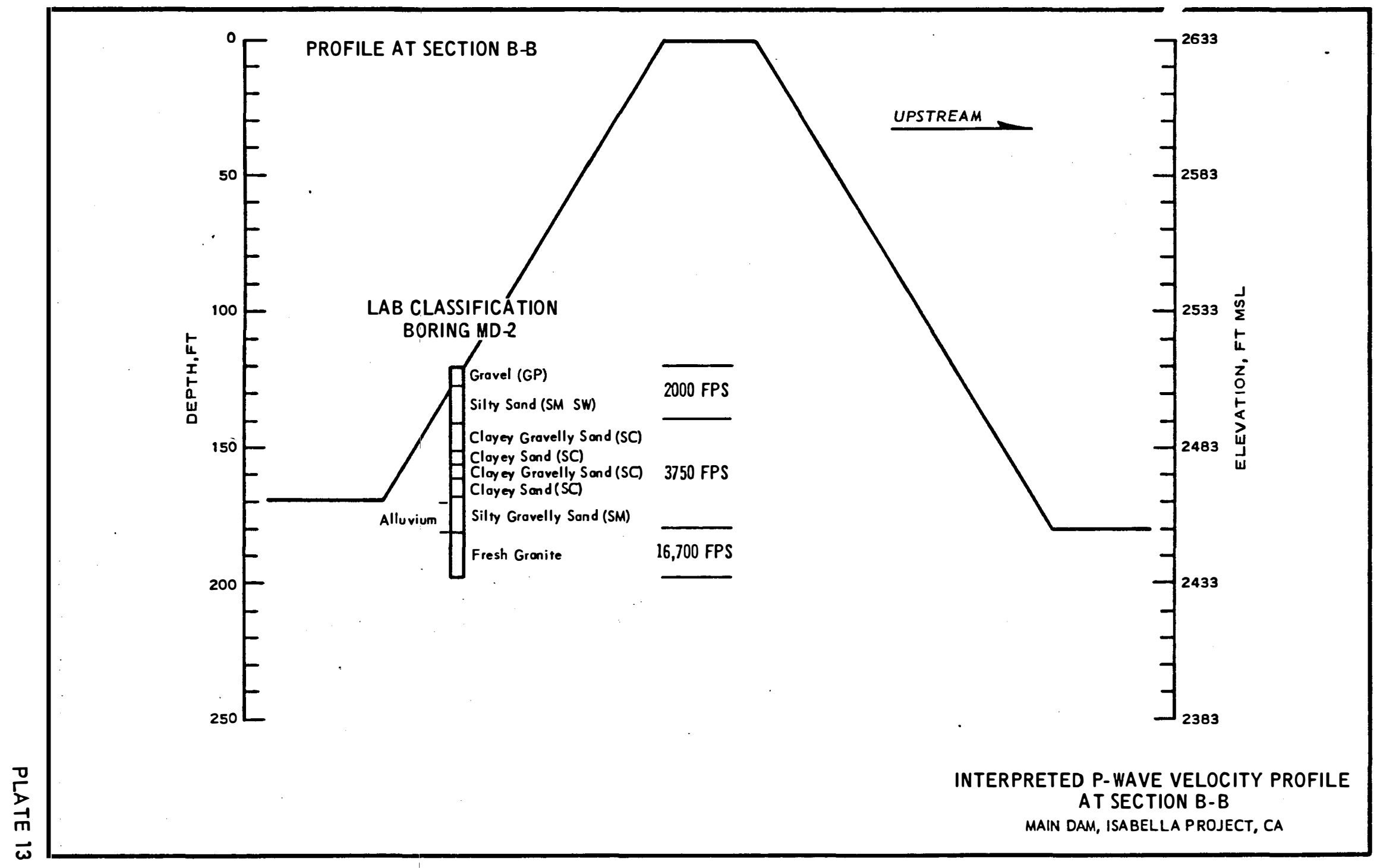




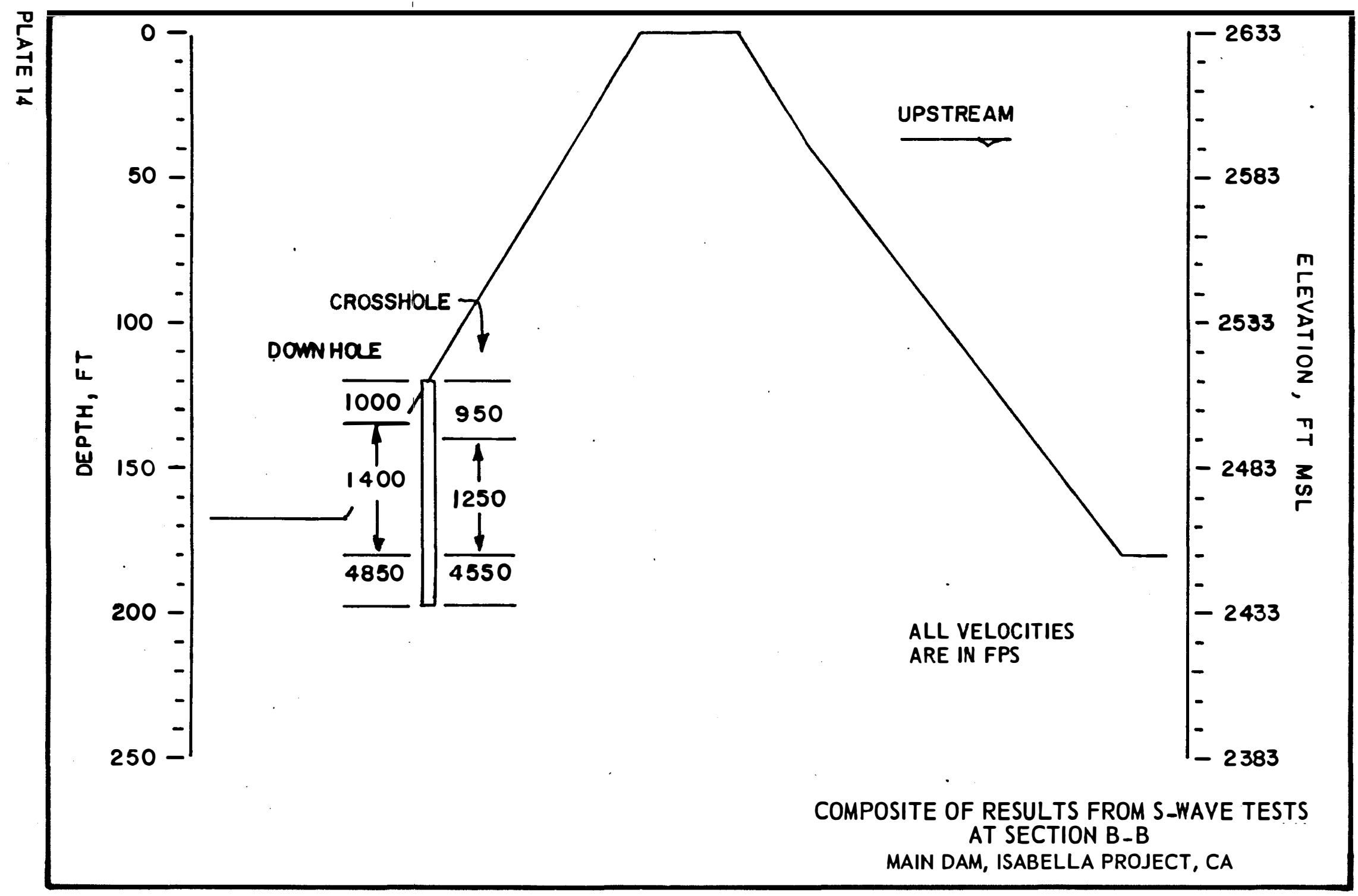




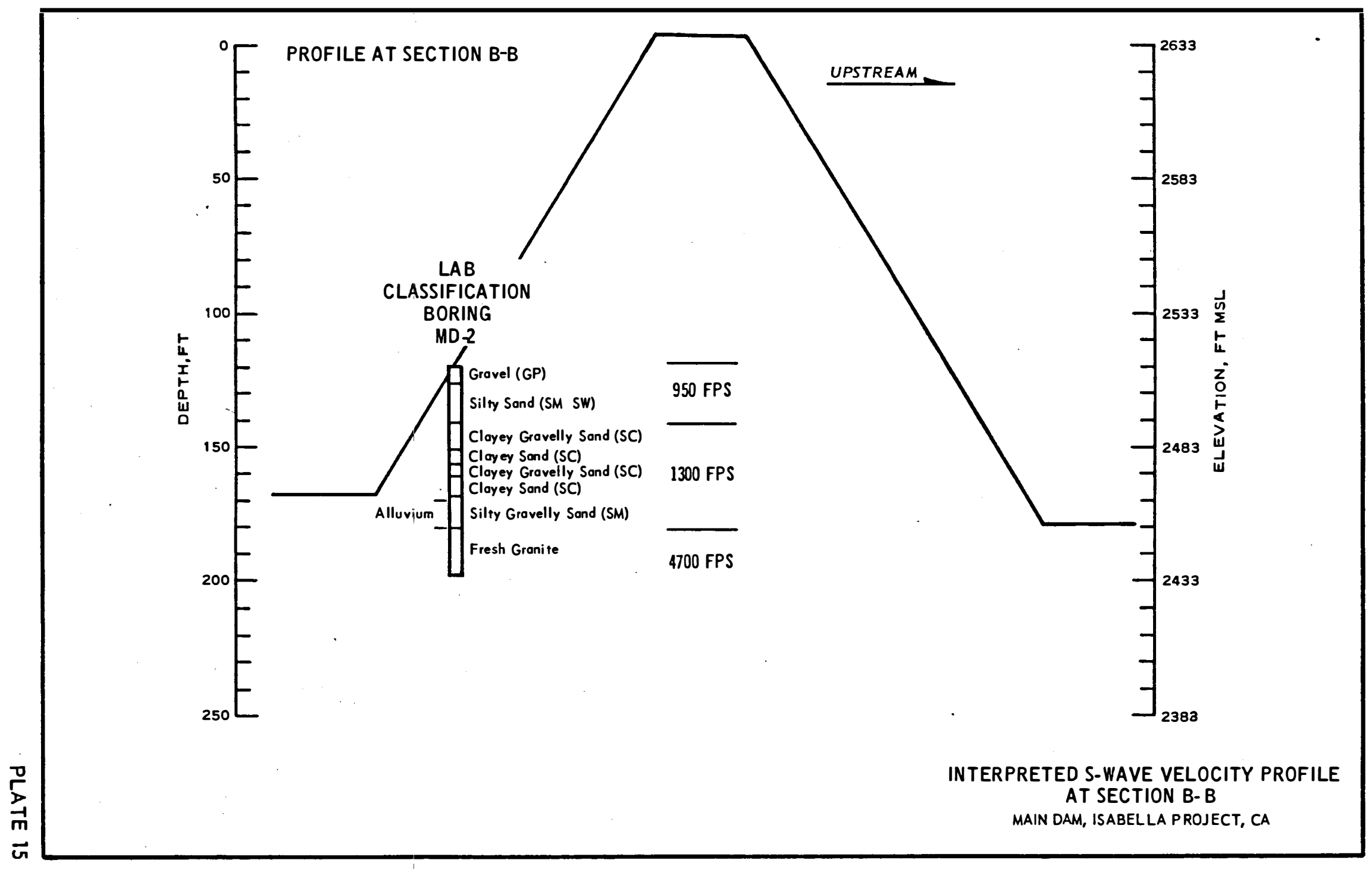




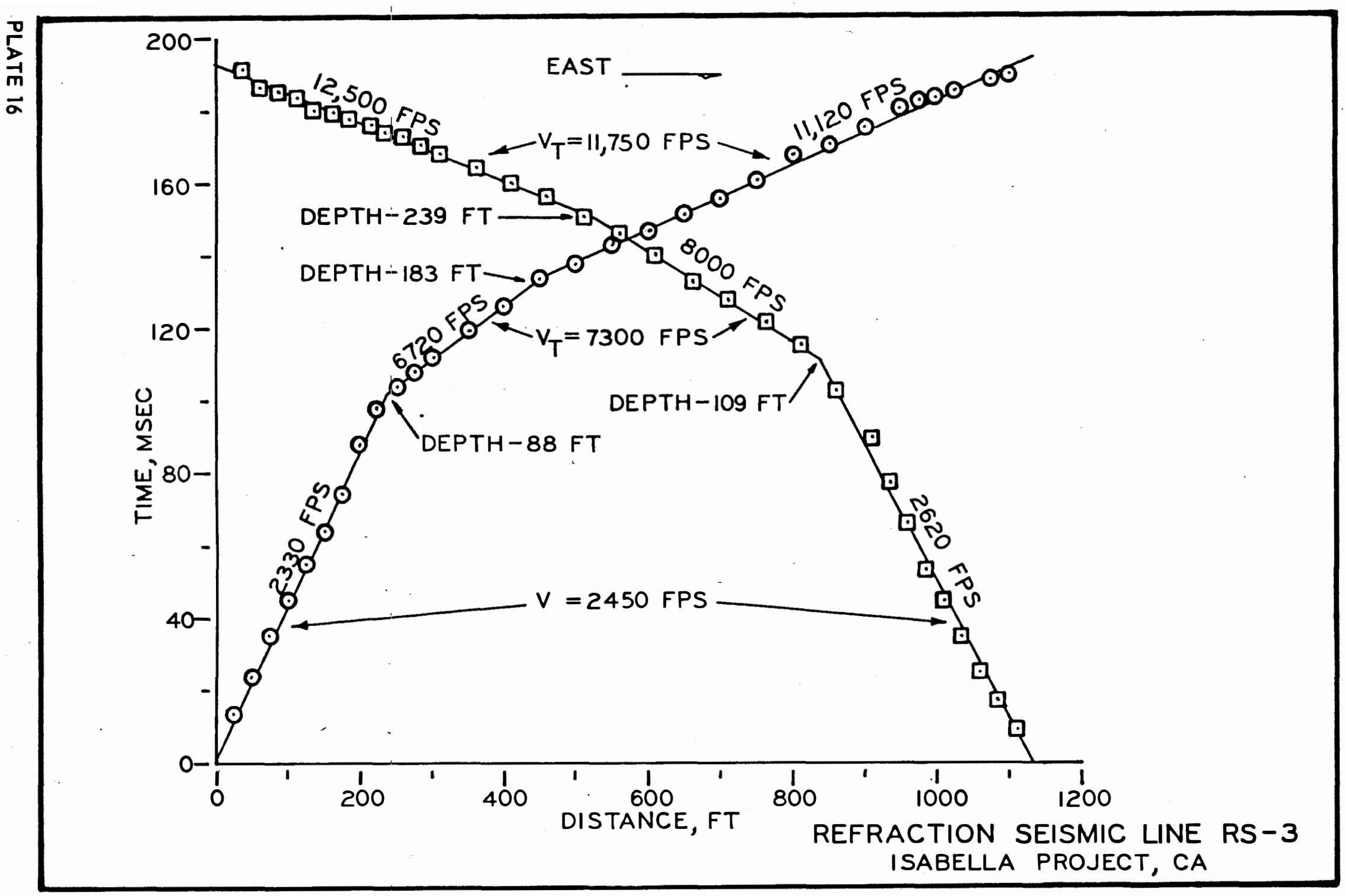




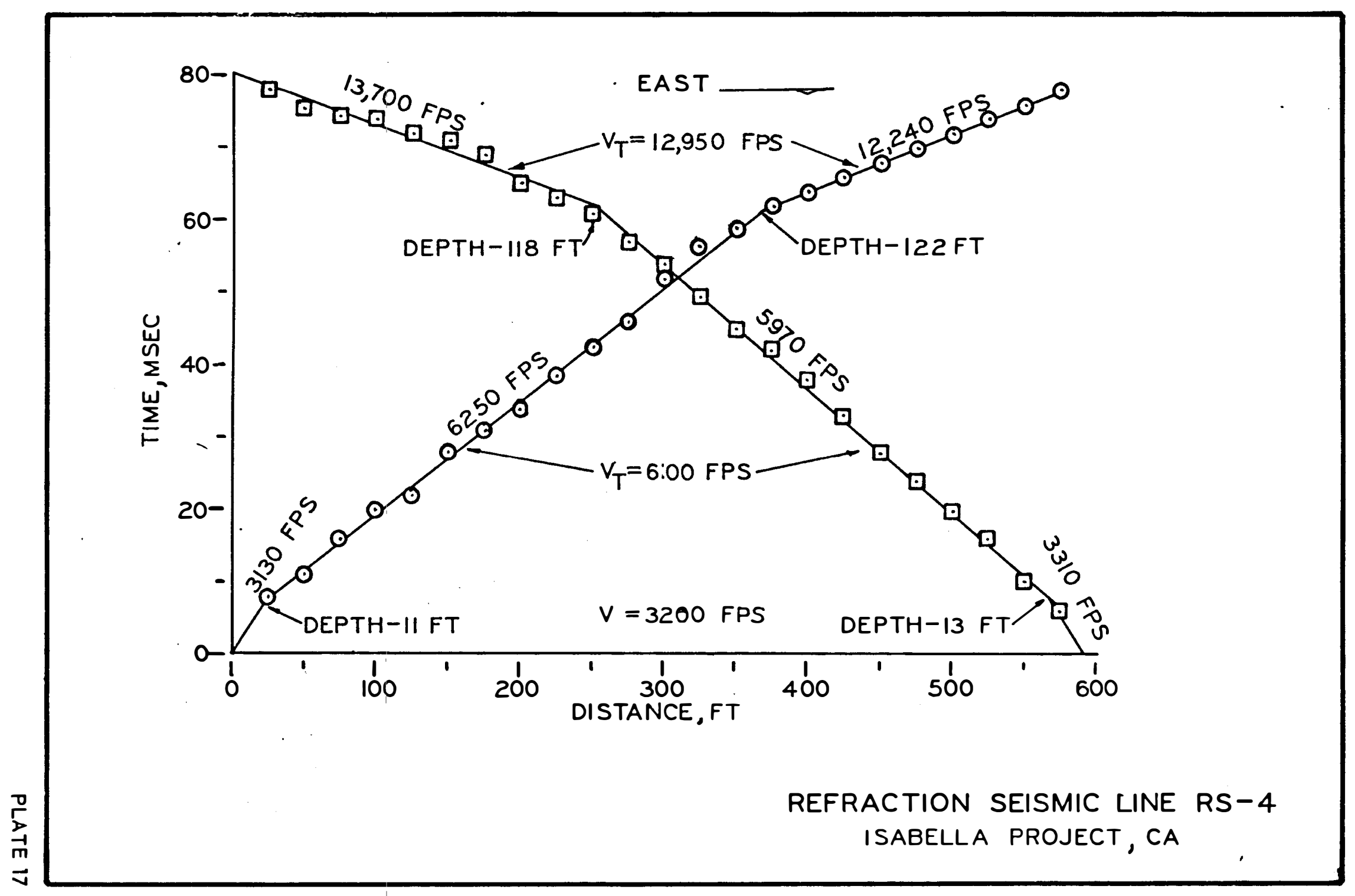




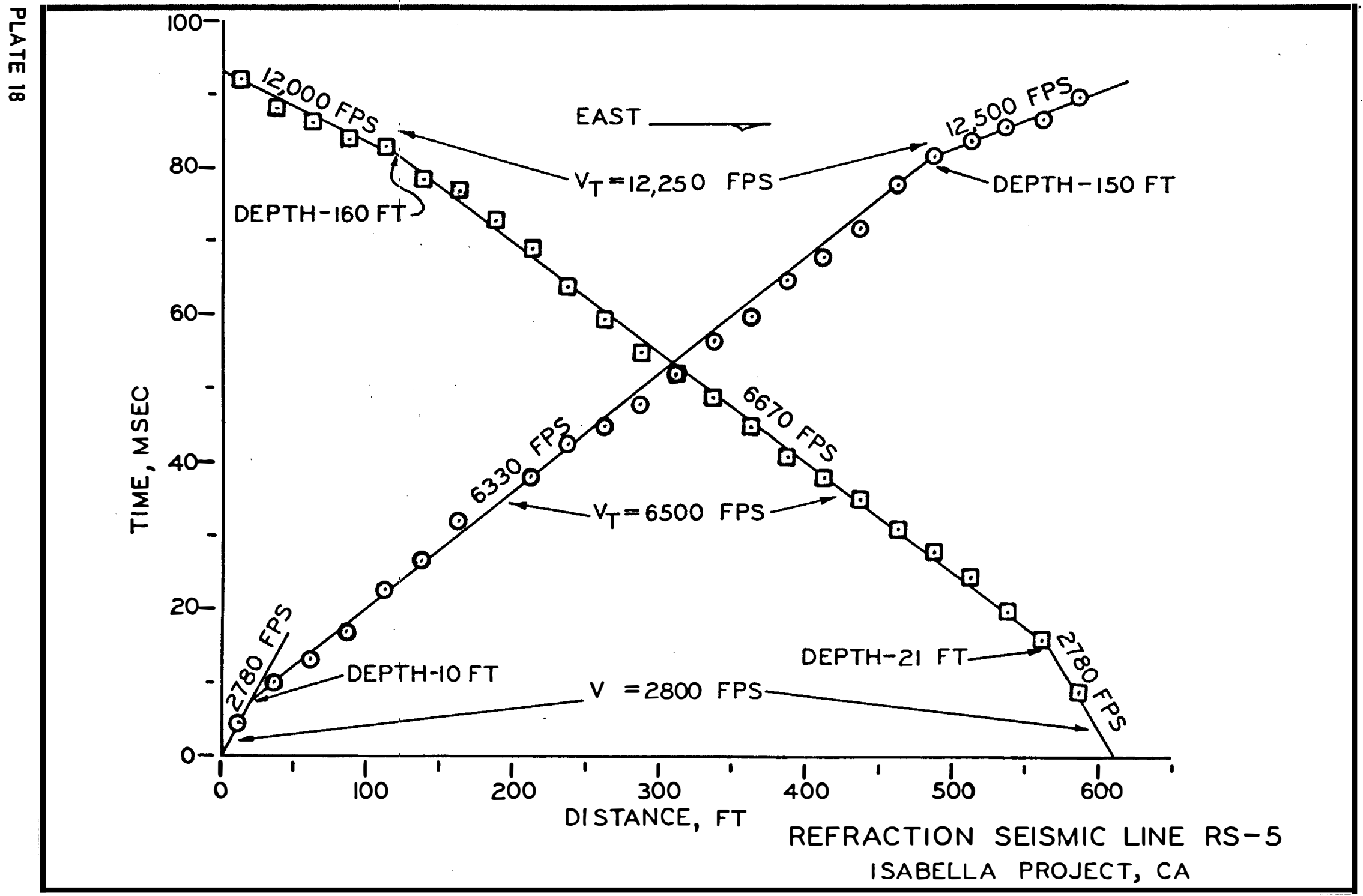




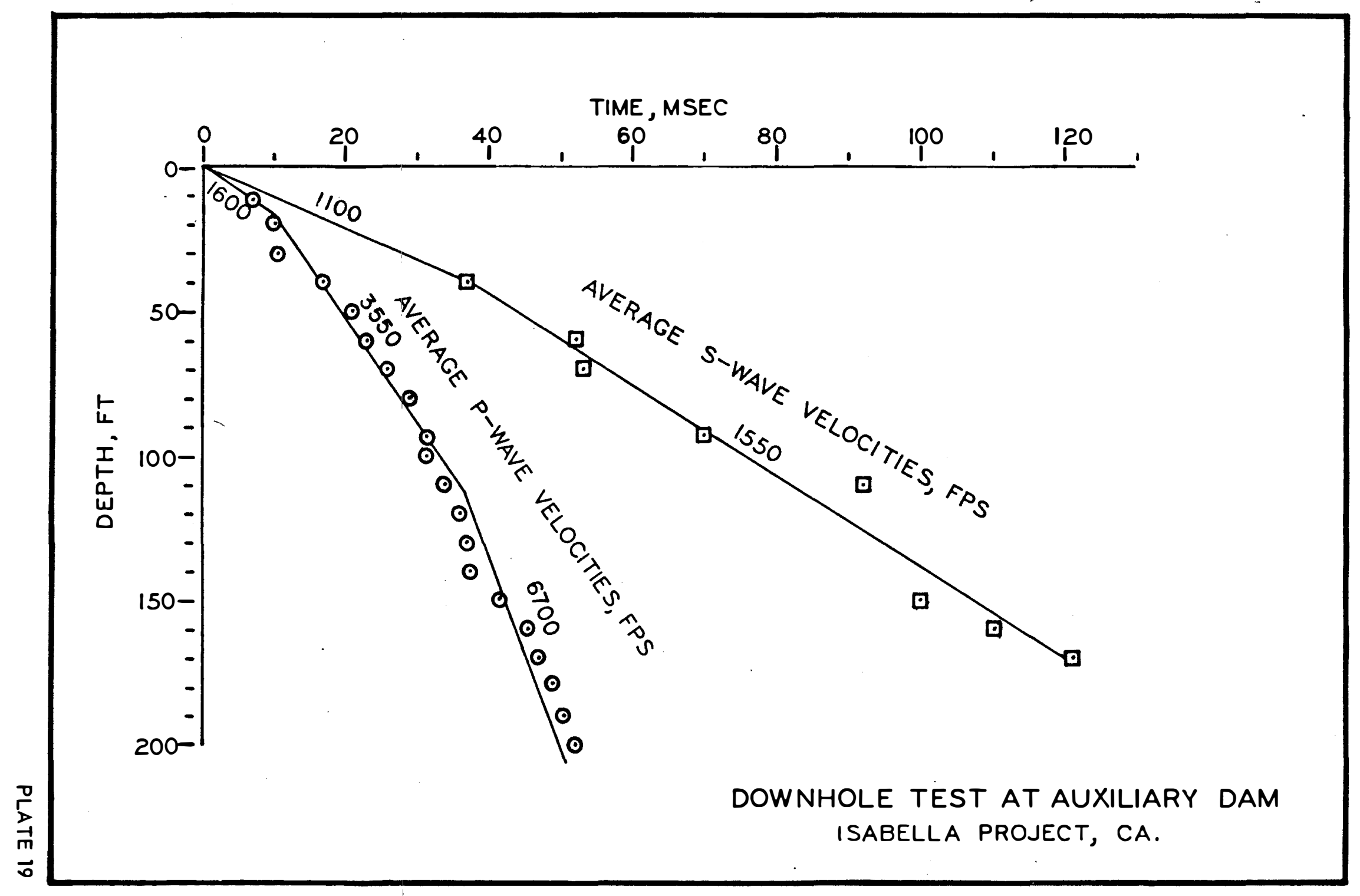




\begin{tabular}{|c|c|c|c|c|}
\hline & CALCULATED & \multirow{2}{*}{\multicolumn{2}{|c|}{ VELOCITY }} & \\
\hline DEPTH & TRUE & & & ELEVATION \\
\hline FT & $\begin{array}{c}\text { VELOCITIES } \\
\text { FPS }\end{array}$ & & $\begin{array}{c}\text { ZONES } \\
\text { FPS } \\
\end{array}$ & $\begin{array}{c}\text { FT MSL } \\
-2633\end{array}$ \\
\hline - & 2460 & $\odot$ & 2450 & - \\
\hline- & 2460 & $\odot \mid$ & & - \\
\hline - & 3740 & $\odot$ & 3550 & - \\
\hline - & 3320 & $\odot$ & & - \\
\hline $50-$ & 2610 & $\odot$ & 2600 & -2583 \\
\hline- & 3770 & $\odot$ & & - \\
\hline - & 3770 & $\odot$ & & - \\
\hline- & 3620 & $\odot$ & 3600 & - \\
\hline- & 3470 & $\odot$ & & - \\
\hline $100-$ & 3470 & $\odot$ & $\longrightarrow$ & -2533 \\
\hline- & 5670 & $\odot$ & 5650 & - \\
\hline- & 6930 & $\odot$ & & - \\
\hline- & 6640 & $\odot$ & & - \\
\hline- & 7100 & $\odot$ & & - \\
\hline $150-$ & 6740 & $\odot$ & 6700 & -2483 \\
\hline- & 6440 & $\odot$ & & - \\
\hline- & 6050 & $\odot$ & & - \\
\hline- & 6910 & $\odot$ & & - \\
\hline- & 7620 & $\odot$ & 7400 & - \\
\hline $200-$ & 7620 & $\odot$ & $\overline{\cos }$ & -2433 \\
\hline & 19000 & $\odot$ & 10,000 & - \\
\hline & 13,420 & $\odot$ & $\longrightarrow$ & - \\
\hline & 13,420 & $\odot$ & & - \\
\hline & 13,420 & $\odot$ & 13,400 & - \\
\hline $250-1$ & 13,420 & | & & $I_{-} 2383$ \\
\hline
\end{tabular}

○ LOCATION OF RECEIVER GEOPHONES

CROSSHOLE P-WAVE VELOCITIES AUXILIARY DIAM, ISABELLA PROJECT, CA 


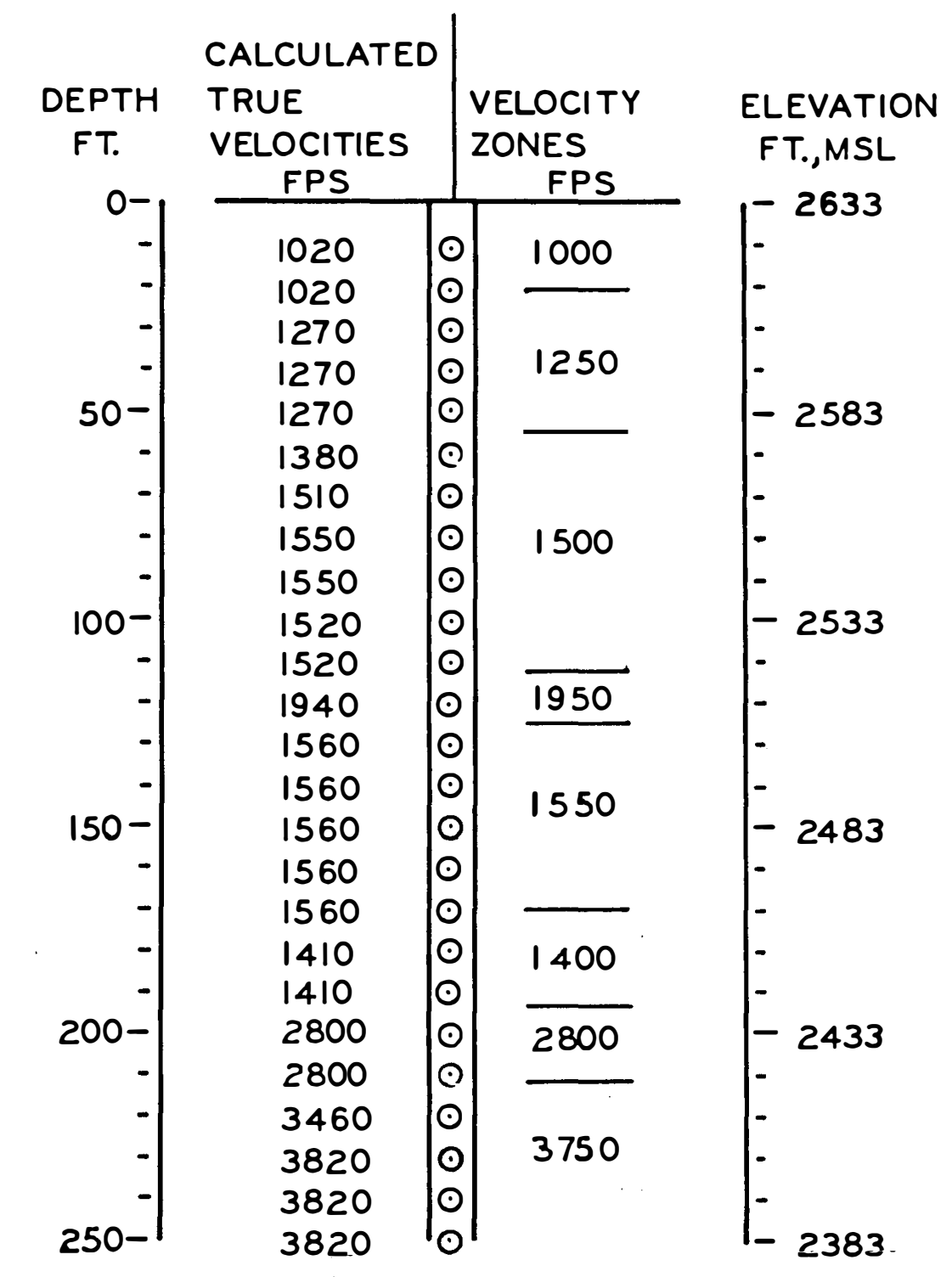

- Location of RECEIVER GEOPHÓNES

CROSSHOLE S-WAVE VELOCITIES AUXILIARY DAM, ISABELLA PROJECT, CA 


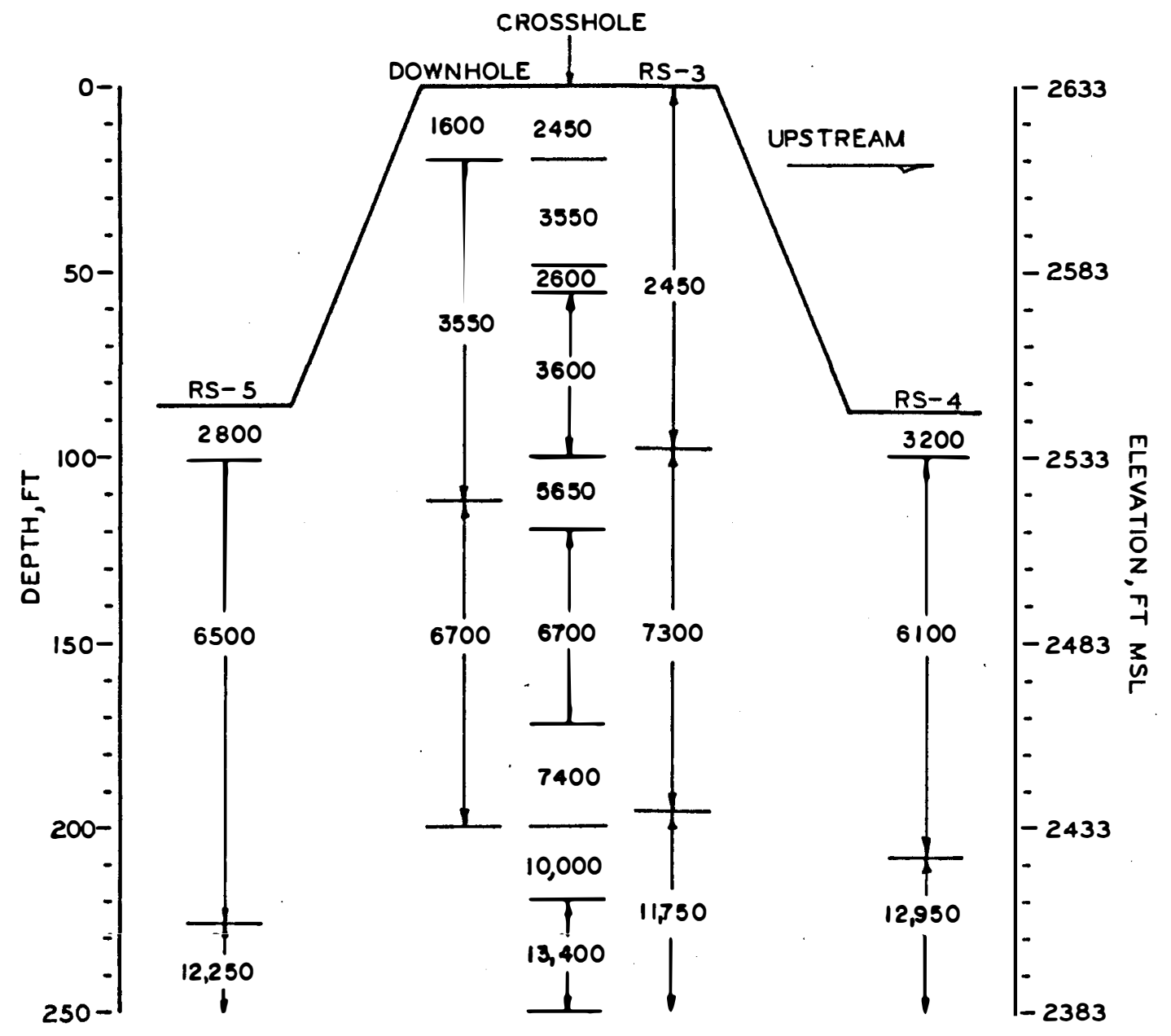

NOTE: ALL VELOCITIES ARE FPS. 


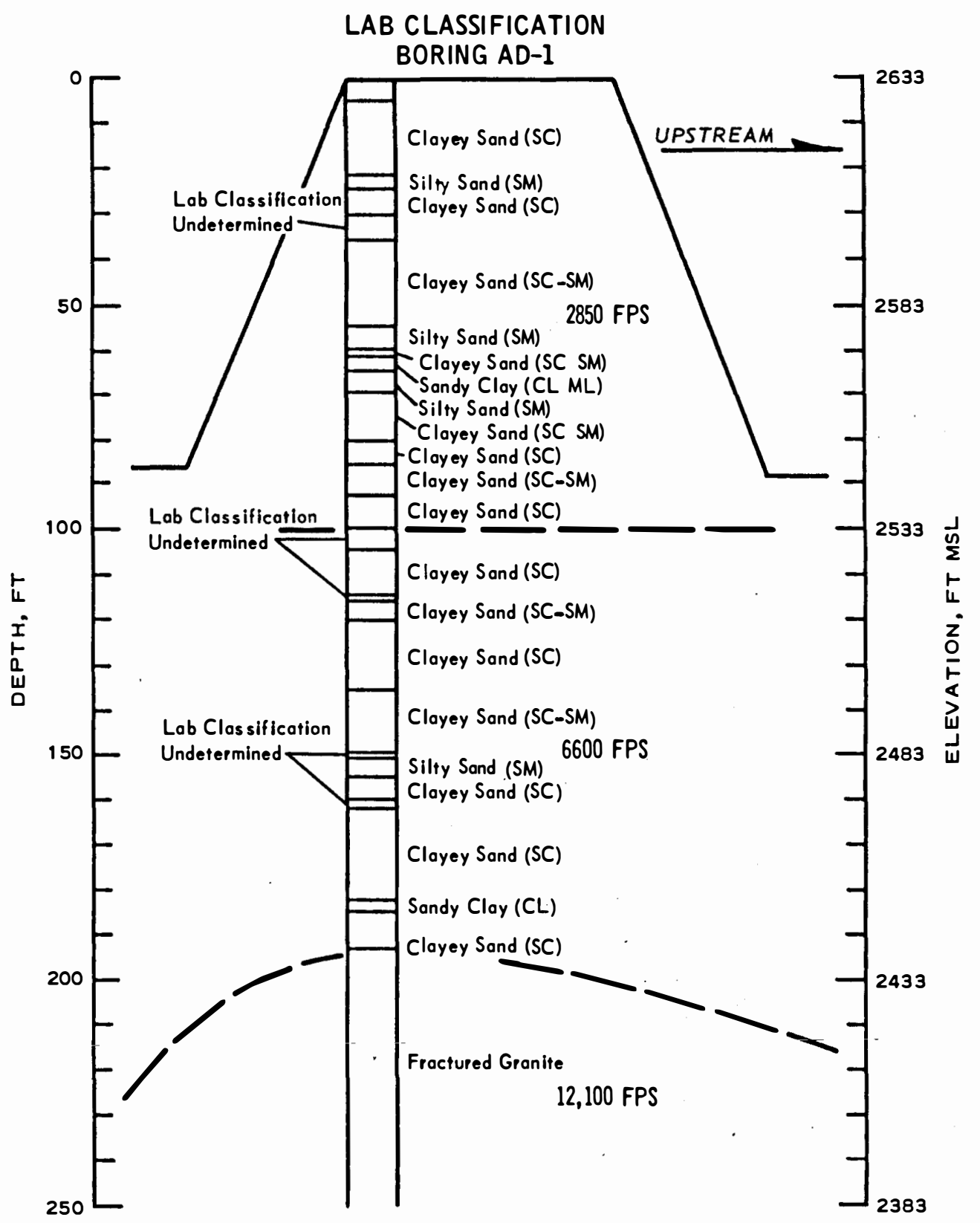

INTERPRETED P-WAVE VELOCITY PROFILE AUXILIARY DAM, ISABELLA PROJECT, CA 


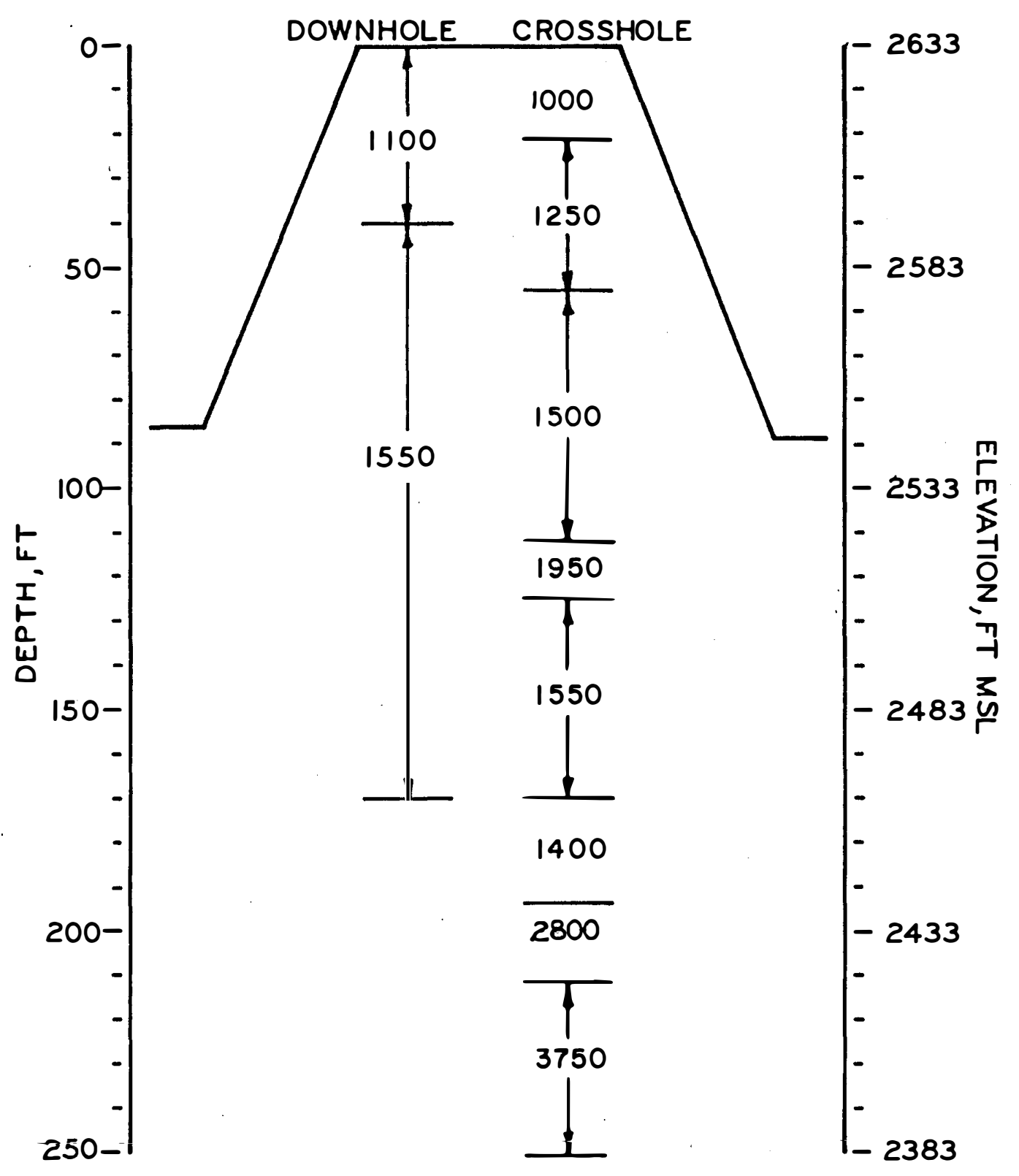

ALL VELOCITIES ARE IN FPS

COMPOSITE OF RESULTS FROM S-WAVE TESTS AUXILIARY DAM, ISABELLA PROJECT, CA 


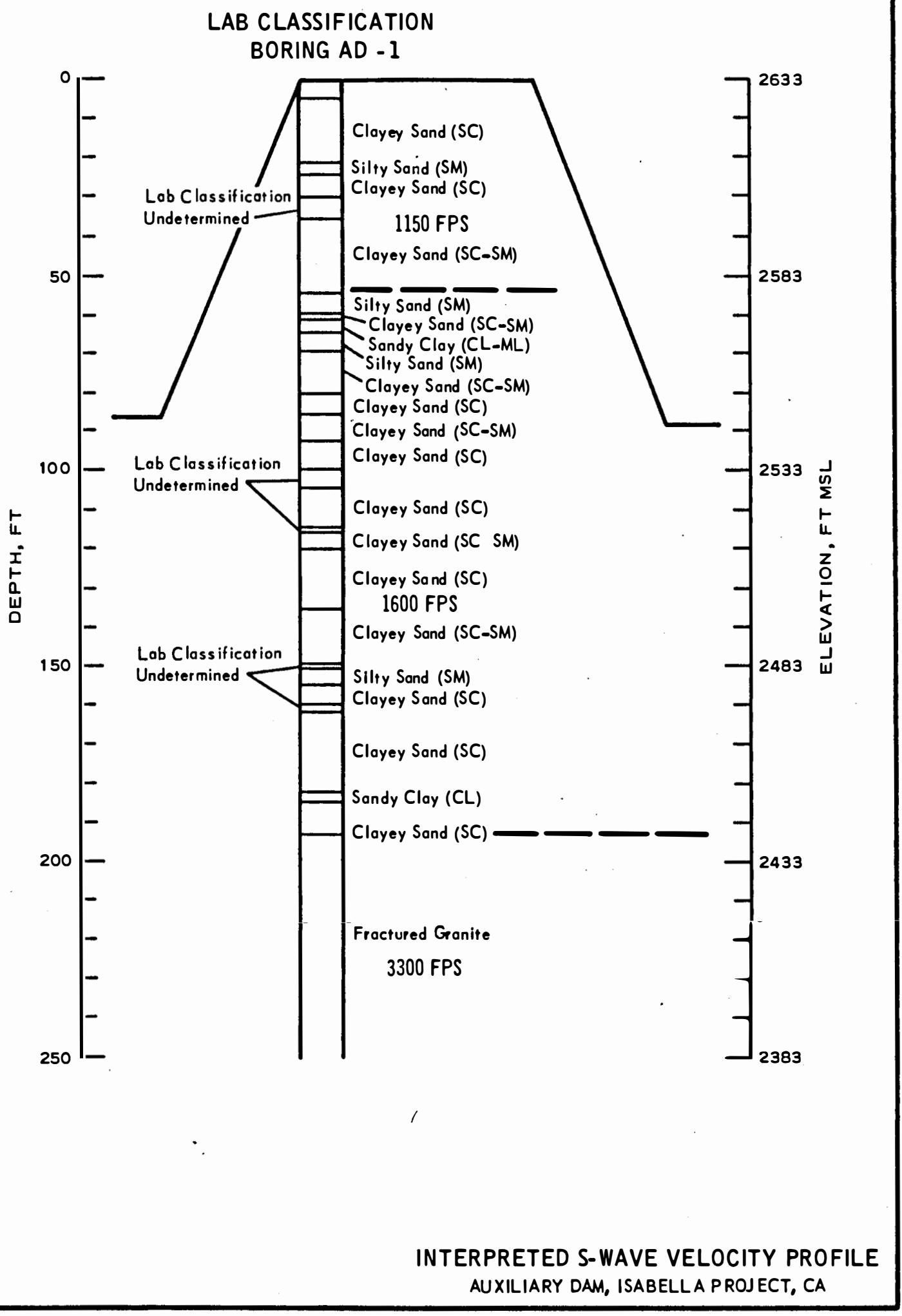




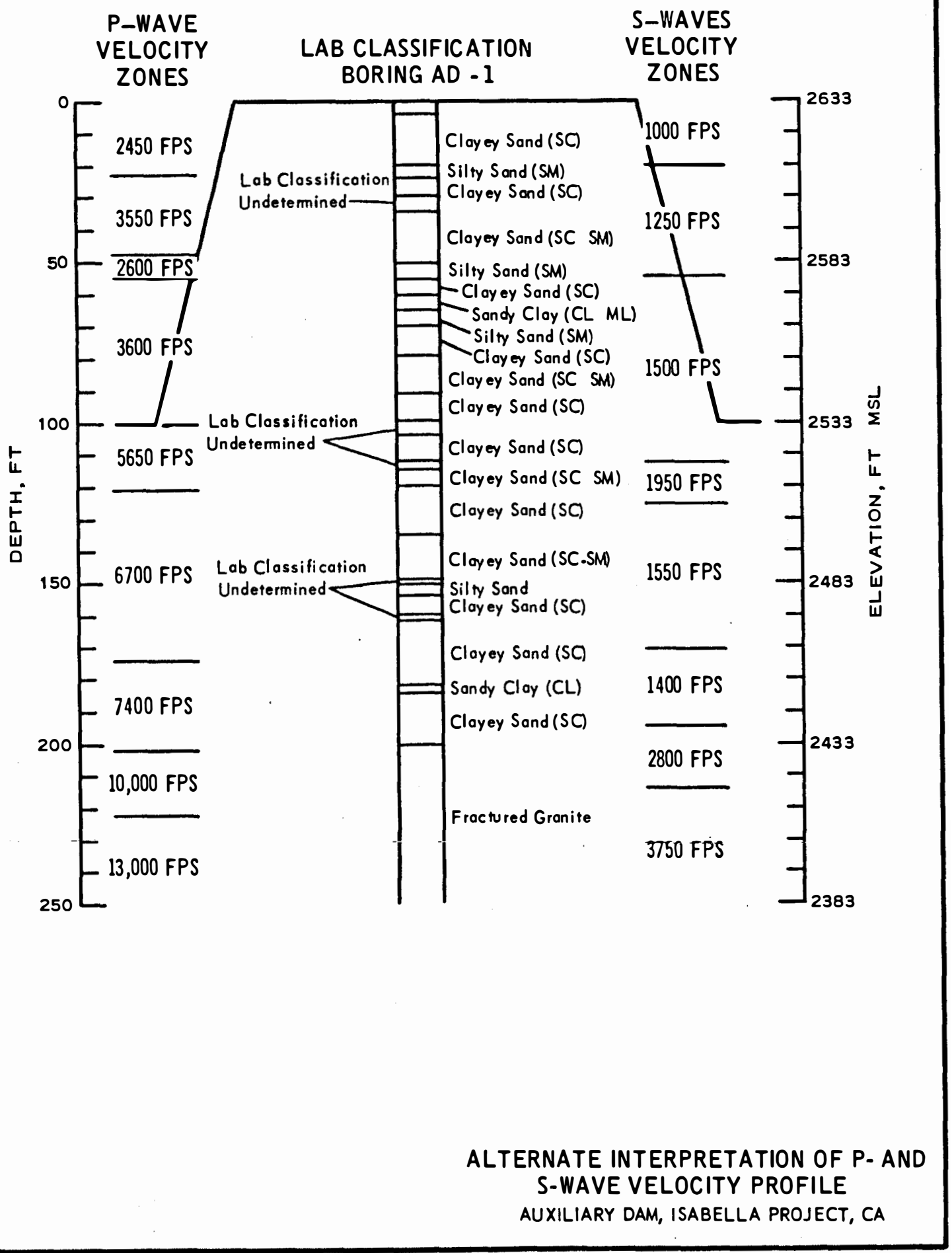

